\title{
The Impact of the Global Financial Crisis on Visitation to the Monongahela National Forest: An Activity-based Segmentation Approach
}

\author{
Connor Braxton Akers \\ West Virginia University, cbakers@mix.wvu.edu
}

Follow this and additional works at: https://researchrepository.wvu.edu/etd

\section{Recommended Citation}

Akers, Connor Braxton, "The Impact of the Global Financial Crisis on Visitation to the Monongahela National Forest: An Activity-based Segmentation Approach" (2020). Graduate Theses, Dissertations, and Problem Reports. 7857.

https://researchrepository.wvu.edu/etd/7857

This Thesis is protected by copyright and/or related rights. It has been brought to you by the The Research Repository @ WVU with permission from the rights-holder(s). You are free to use this Thesis in any way that is permitted by the copyright and related rights legislation that applies to your use. For other uses you must obtain permission from the rights-holder(s) directly, unless additional rights are indicated by a Creative Commons license in the record and/ or on the work itself. This Thesis has been accepted for inclusion in WVU Graduate Theses, Dissertations, and Problem Reports collection by an authorized administrator of The Research Repository @ WVU. For more information, please contact researchrepository@mail.wvu.edu. 


\title{
The Impact of the Global Financial Crisis on Visitation to the Monongahela National Forest: An Activity-based Segmentation Approach
}

\begin{abstract}
Connor Akers
Thesis Submitted to the Davis College of Agriculture, Natural Resources, and Design at West Virginia University in partial fulfillment of the requirements for the degree of
\end{abstract}

Master of Science in Recreation, Parks and Tourism Resources Management

Chad D. Pierskalla, Ph.D., Jinyang Deng, Ph.D., David Smaldone, Ph.D.

Division of Forestry and Natural Resources Recreation, Parks \& Tourism Resources

Morgantown, West Virginia 2020

Keywords: Financial Crisis; Market Segmentation; Activity Based Segmentation; Monongahela National Forest Copyright 2020: Connor Akers 


\section{Abstract \\ The Impact of the Global Financial Crisis on Visitation to the Monongahela National Forest: An Activity-based Segmentation Approach}

\section{Connor Akers}

Research on recreational use market segments and trends are essential for determining how tourism businesses can better meet the needs of their customers and find new target markets especially during challenging times. The purpose of this study is to determine how recreation participation has changed over five years on the Monongahela National Forest following the world financial crisis in 2008. Data used for this research were collected with the National Visitor Use Monitoring (NVUM) surveys in fiscal years 2009 and 2014. NVUM surveys are onsite interviews conducted at the end of a visit. The surveys produce descriptive information about visitors. NVUM uses a stratified random sampling methodology to collect data for each use level (e.g., low, medium, high, or very high) and site type (e.g., Day Use Developed Sites, Overnight Use Developed Sites, General Forest Areas, and Wilderness Sites). Data were collected during a 12-month period and a total of 1,851 interviews were completed. Two step cluster analysis of 18 activity participation variables (binary data) was conducted with 5 clusters specified. The clusters include Relaxing in Nature Package, Backpacking and Hiking Package, Viewing Nature Package, Picnicking Package, and Purely Fishing. Changes in demographics, overall satisfaction, and trip spending were examined for each market segment. Market winners and losers were identified helping tourism providers develop more efficient strategies both locally and regionally. 


\begin{abstract}
All rights reserved
INFORMATION TO ALL USERS The quality of this reproduction is dependent on the quality of the copy submitted.
\end{abstract}

In the unlikely event that the author did not send a complete manuscript and there are missing pages, these will be noted. Also, if material had to be removed, a note will indicate the deletion.

\begin{abstract}
All rights reserved. This edition of the work is protected against unauthorized copying under Title 17, United States

Code.
\end{abstract}

UMI Number: 1504874 


\section{Dedication}

To my family, friends, and colleagues for their outstanding support. 


\section{Acknowledgement}

The authors would like to thank Don English, Program Manager for the National Visitor Use

Monitoring Program, for providing the data used in this study. 


\section{Table of Contents}

Chapter

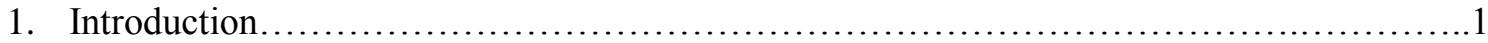

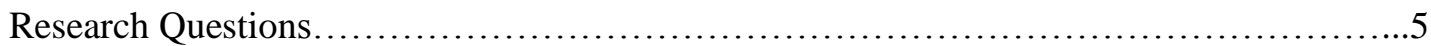

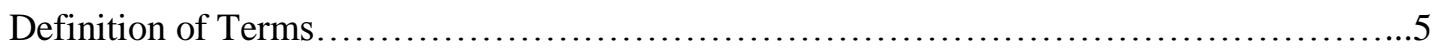

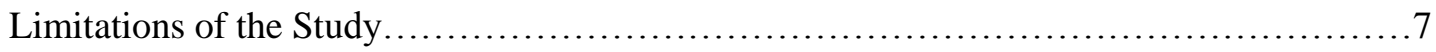

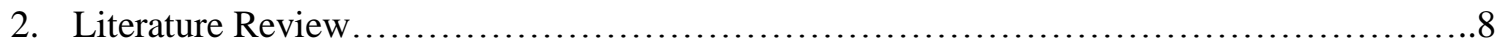

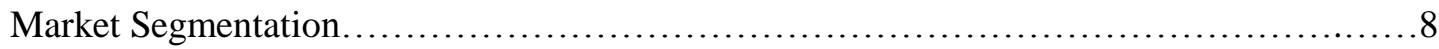

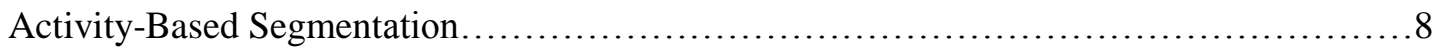

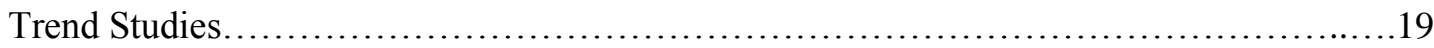

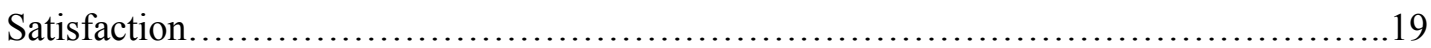

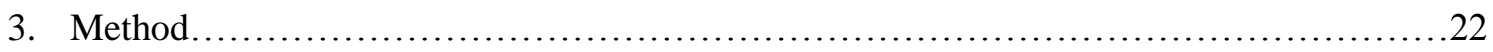

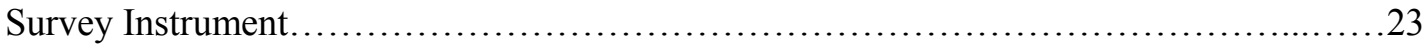

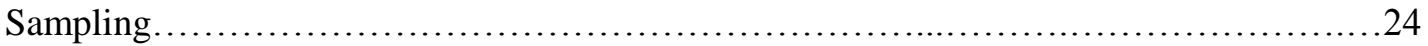

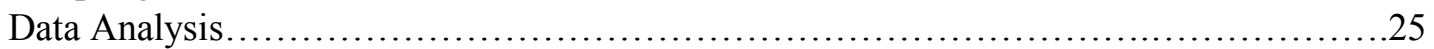

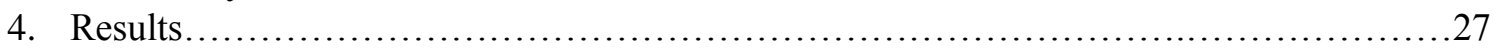

Segmentation Procedure.......................................................... 27

Relaxing in Nature Package...................................................... 27

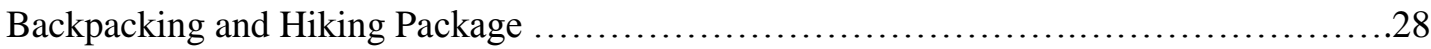

Viewing Nature and Hunting Package.............................................. 28

Picnicking Package ............................................................ 28

Purely Fishing................................................................. 28

Fiscal Year Differences in Cluster Membership..................................... 31

Fiscal Year differences in Demographics........................................... 31

Respondent Location by Fiscal Year and Cluster..................................... 35

Fiscal Year and Cluster Membership Differences in Travel Distance.......................42

Fiscal Year and Cluster Membership Differences in Trip Spending.......................43

Fiscal Year and Cluster Membership Differences in Nights Spent Away From Home.......44

Fiscal Year and Cluster Membership Differences in Overall Satisfaction..................45

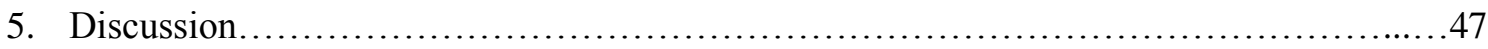

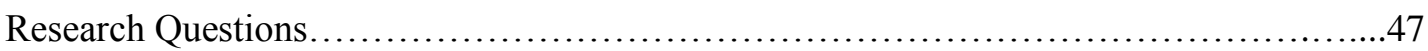

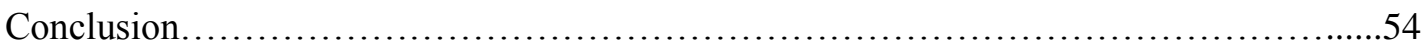

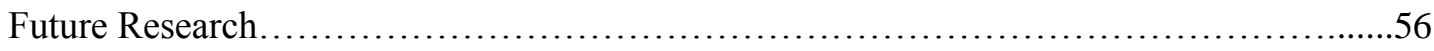

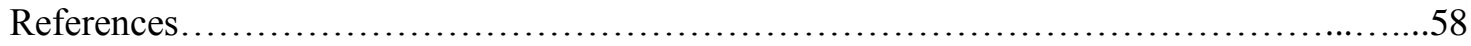

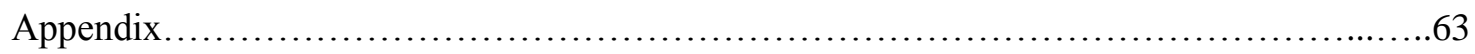




\section{List of Figures}

Figure 1: Distribution of survey sites...................................................................24

Figure 2: Distribution of home zip codes for FY 2009, Cluster 1 Visitors.........................37

Figure 3: Distribution of home zip codes for FY 2014, Cluster 1 Visitors.........................37

Figure 4: Distribution of home zip codes for FY 2009, Cluster 2 Visitors..........................38

Figure 5: Distribution of home zip codes for FY 2014, Cluster 2 Visitors.........................38

Figure 6: Distribution of home zip codes for FY 2009, Cluster 3 Visitors.........................39

Figure 7: Distribution of home zip codes for FY 2014, Cluster 3 Visitors..........................39

Figure 8: Distribution of home zip codes for FY 2009, Cluster 4 Visitors.........................40

Figure 9: Distribution of home zip codes for FY 2014, Cluster 4 Visitors.........................40

Figure 10: Distribution of home zip codes for FY 2009, Cluster 5 Visitors.......................41

Figure 11: Distribution of home zip codes for FY 2014, Cluster 5 Visitors.......................41 


\section{List of Tables}

Table 1: Activity segmentation literature updated from Schneider, Vogt, and Smith (2006).....13

Table 2: Description of NVUM Survey Forms.............................................................23

Table 3: Activity participation by cluster membership....................................................29

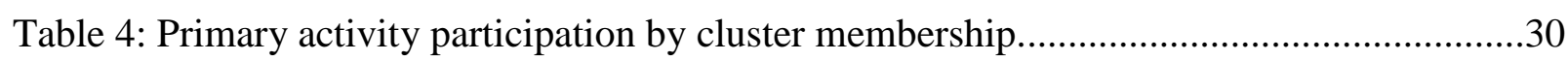

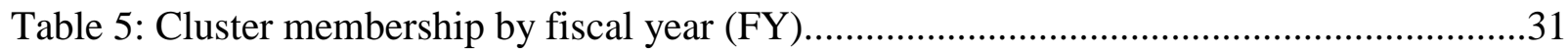

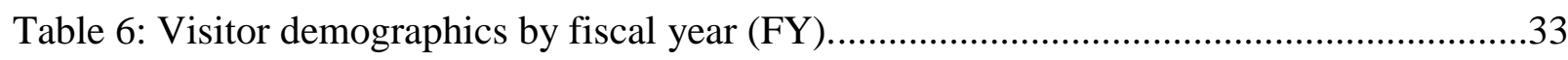

Table 7: ANOVA summary table for travel distance........................................................42

Table 8: Descriptive statistics for travel distance ..........................................................42

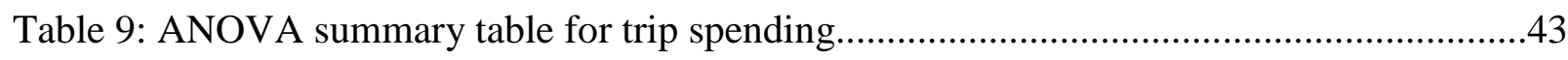

Table 10: Descriptive statistics for trip spending..........................................................4

Table 11: ANOVA summary table for nights away from home........................................45

Table 12: Descriptive statistics for nights away from home ............................................45

Table 13: ANOVA summary table for overall satisfaction..............................................46

Table 14: Descriptive statistics for overall satisfaction.......................................................46 


\section{Introduction}

Participation in recreational activities have widely varied throughout the years across America (Attarian, 2001). Over time, recreation trends have changed and new activities have emerged in outdoor recreation. The Monongahela National Forest in West Virginia is no exception to the change in activities. Due to the wide variety of uses for the Monongahela National Forest, understanding different levels of use is beneficial in future planning and management of the forest. Knowing the change in levels of use in recreational activities is beneficial for managers to update the management plans for different areas of the forest. Because of the variability in the usage of the forest, research on recreation participation is important to determine the proper management of the forest. Recreational participation stems from the activities that are shared by visitors throughout the forest areas (Askew, Bowker, English, Zarnoch, \& Green, 2017). In the Monongahela National Forest, visitors participate in a diverse number of recreational activities. Common interests in usage of the forest areas for recreation include, but are not limited to hiking, camping, biking, hunting, fishing, viewing nature, etc. (Askew, Bowker, English, Zarnoch, \& Green, 2017).

The recent outbreak of Coronavirus (COVID-19) and its impact on the global economy is a reminder that tourism and crisis is a never-ending and ever-changing story, and when new events and impacts occur, we should learn from them. Previous to that outbreak, travel and tourism was hit hard by the 2008-2009 financial crisis which was the deepest recession since the Great Depression (Meng, Siriwardana, Dollery, \& Mounter, 2010; WTTC, 2010). The crisis was caused by the credit and housing market collapses (Coles, 2013). Visser and Ferreira (2013) argue that the impacts of economic downturns, such as the one in fiscal year 2009, illustrate the integration of the world's economies, transport systems, media and communication networks. 
The deep economic crisis severely affected employees' work and personal lives. Hochwarter (2009) showed that 70 percent of both men and women in his study confirmed that the recession increased stress levels. More than 70 percent also admitted making spending changes, including limiting or eliminating the purchase of non-essential items. Mucci, Giorgi, Roncaioli, Perez, and Arcangeli (2016) implemented a systematic review of the principal studies that examined the impact of the crisis on the health of workers. A total of 19 articles were reviewed. All of the studies showed that the crisis was a stressor that impacted workers' mental health. There were increases in mood disorders, dysthymia, anxiety disorders, somatoform disorders, panic attacks, and abuse of alcohol.

The impact of the macro-economic event on tourism was also felt all around the world because the purchasing power of people significantly influences their decisions to travel (Mihalič, Kester, \& Dwyer, 2013). Global GDP generated by travel and tourism declined by $4.8 \%$ in 2009 with estimated job losses of almost 5 million in this industry (WTTC, 2010). In Singapore, tourism declined by $13.5 \%$ in the first half of 2009 (Meng, Siriwardana, Dollery, \& Mounter, 2010). In Asia, arrivals significantly declined (Song \& Lin, 2010). In the United Kingdom, the greatest declines were from European countries (e.g., Germany, Ireland, and Spain) and the US (Visser \& Ferreira, 2013). Within Europe, a contraction of travel in time and space was reported. That is, "the average German's current approach...can be described in the following way: closer, shorter, cheaper" (Reinhardt, 2011, p. 27). In Canada, spending by total tourism demand had the first decline since being hit by SARS (Ritchie, Molinar, \& Frechtling, 2010). In Mexico, arrival of international tourists grew by 5\% in the first half of 2008 and plunged to $-1 \%$ by the end of the year (Richie et al., 2010). And in the US, by the end of the first 
quarter in 2009, real travel demand had fallen 6\% over six quarters (Richie, Molinar, \& Frechtling, 2010).

The 2008 financial crisis played a role in tourists' motivation to travel. Rittichainuwat, Chakraborty, and Rattanaphinanchai (2014) found that novelty, culture, and safe and shortdistance destinations would motivate tourists to travel during financial crises. During a time of financial hardship, tourists may be more prudent with their spending. Rittichainuwat, et al. (2014) found that during a financial crisis a safe and short-distance destination becomes a popular travel alternative because it saves time, effort, and travel costs. Because of the crisis, many tourism bureaus launched marketing campaigns to encourage tourists to travel to their destinations in an attempt to generate tourism income and help heal the economic crisis. During the crisis, the largest ever decline in passenger air transportation and a decrease of travel demand in the United States occurred (Rittichainuwat et al., 2014). The study conducted by Rittichainuwat, et al. (2014) found that recreational activities such as spa treatments, shopping, and golfing may have been perceived as wasteful during the time of the crisis and people felt as if their money was better spent elsewhere. Their study also showed that during that time the demand for shopping and similar activities also decreased along with a decrease in secondary vacations and short trips.

The housing market was severely affected by the 2008 crisis but the same cannot be said for the stock market, at least not early into the crisis. According to Birru and Figlewski (2011), U.S. stock prices hit their all-time high in October 2007, when the S\&P 500 Index reached 1,576.09. Over the course of a few months the S\&P fell over 500 points and was being traded below 800 by the end of 2008. During this time, expectations for the U.S. market were full of uncertainty and investors were experiencing significant financial losses. The combination of financial losses 
and market uncertainty greatly reduced the willingness of investors to take risk. The S\&P 500 reached its lowest point in March of 2009 when it was being traded for under 700 and then began to increase over time (Birru \& Figlewski, 2011).

Impacts from the global economic downturn imply that the effects have been ubiquitous and the same negative patterns were experienced universally. In fact, the popular media was well supplied with stories about the challenges faced by the travel and tourism industry during the financial crisis (Coles, 2013), but little research has been published at smaller scales. For example, there is a lack of literature specifically on crisis-impacted market segments. There have been winners and losers within tourism (Coles, 2013), and perhaps they can be more easily identified within smaller markets or at smaller scales like a National Forest. When market segments are better understood, more efficient strategies can be developed to meet the needs of target markets, attract new markets, promote product development, better allocate marketing resources, manage visitor conflict, or increase customer volume in off-peak periods (Choi \& Tsang, 2008; Mumuni \& Mansour, 2014).

Research on the global financial crisis and how it affected recreational use trends are also essential for determining how tourism businesses can better meet the needs of their customers and find new target markets (Siniscalchi, Pierskalla, Selin, \& Palmer, 2006). It is also important to discover how participation has changed over five years on the forest. The research purpose of this study is to examine visitor use surveys and recreation activity participation throughout those five years, especially following the world financial crisis of 2008-2009. Data collection started on October 1, 2008 just two weeks after Lehman Brothers filed for bankruptcy, which was near the beginning of the crisis. 


\section{Research Questions}

- How has recreation participation changed over five years on the Monongahela National Forest following the world financial crisis in fiscal year 2009?

- What are the activity-based market segments?

- For each market segment, is there a difference in visitor demographics for fiscal years 2009 and $2014 ?$

- What are the main and interaction effects of fiscal year and cluster membership on travel distance, trip expenditures, nights away from home, and overall satisfaction?

- Was the "global economic downturn" ubiquitous across all market segments?

- Are the 5 activity packages proposed by Hendee, Gale, and Cotton (1971) represented on the Monongahela National Forest?

- How much activity variety exists within each activity package on the Monongahela National Forest?

\section{Definition of Terms-}

1. Financial Crisis - According to Edey (2009), a financial crisis can cause a severe economic shock to a country. For example, the 2008 financial crisis was one of the most significant economic shocks in the United States. When a financial crisis occurs there is a chance for global economic fallout. Edey (2009) further suggests that during a crisis, it is ordinary to see a large swing in the appetite of world financial markets for risk, and in 
their capacity to accept risk. This can also be accompanied by a loss in consumer confidence, causing impacts to the global economy.

2. Market Segmentation - According to Choi, Murray, and Kwan, (2011), segmentation defines subgroups of consumers so that there can be a better understanding of the subgroups' needs and wants. In market segmentation, subgroups can be divided into a variety of groups such as age groups, income brackets, or hobbies (Choi et al., 2011). Furthermore, they state that the main benefits of market segmentation are efficient use of limited resources, better communication with target customers, increased customer satisfaction, strengthened competitive position, and maximized sales and profits.

3. Activity Based Segmentation - Activity based segmentation defines forest visitors based on their choice of recreational activities and overall behavior during their visits (Pesonen \& Tuohino, 2015). It is used to better understand the past and for predicting behavior (Choi et al., 2011). Understanding activity segments provides the opportunity to improve profitability, attract new target markets, and increase traveler volume. 


\section{Limitations of the Study}

1. There is lack of causation that can be proven in a trend study and there may have been other factors that contributed to our results. However, the financial crisis was the dominant news event during fiscal year 2009 and our data collection was well timed during that period.

2. There is a lack of literature on trend studies. There is an example of another trend study that examined the potential impacts of an event on visitation. Riley, Pierskalla, Burns, Maubme, Graefe, Smaldone, \& Williams, (2015) conducted a trend study to examine the displacement of OHV users 3 years after a restrictive management policy was implemented at Oregon Dunes National Recreation Area and Sand Lake. However, not all events are planned. NVUM can provide valuable trend data when major events suddenly occur in society or at a recreation area and may provide our best option for examining those impacts on visitation.

3. The source of the data came from a previous study (National Visitor Use Monitoring). A limitation of pre-existing data is that it can rarely be independently verified. In the 2009 and 2014 study years, teams of surveyors conducted surveys, thus there is potential for errors in the survey interviews. 


\section{Literature Review}

To better understand recreation activity participation and the role of the 2008-2009 financial crisis played on the Monongahela National Forest, this section focuses on previous studies and literature related to this study. This section will discuss market segmentation, activity-based segmentation, trend studies, and satisfaction.

\section{Market Segmentation}

Market segmentation is at the heart of modern marketing (Schneider, Vogt, \& Smith, 2006), and is one of the most important management tools of the recreation and tourism planner (Schroeder, 1987). Market segmentation in the tourism industry involves grouping tourists into homogenous categories based on the similarity with one or more variables including travel motivation, benefits sought, travel mode, expenditure amounts and patterns, and preferences for tourism activities, among others (Mumuni \& Mansour, 2014). Statistical techniques such as factor and/or cluster analysis are used to identify the distinct segments when using a posteriori approach (versus identifying clusters a priori). The resulting segments are then profiled based on similarity with other variables such as sociodemographics.

\section{Activity-based Segmentation}

When the crisis of 2008 began (e.g., when the housing market declined), not only was the real economy affected, the financial system was affected too (Okte, 2012). According to Okte (2012), people were making poor decisions in the real estate market for years that affected the global economic conditions. The World Financial Crisis of 2008 affected many people financially and potentially changed their recreation trends. For this research on the Monongahela National Forest, activity-based segmentation was the primary focus of the study. According to Pesonen 
and Tuohino (2015), activity-based segmentation defines forest visitors based on their choice of recreational activities and overall behavior during their visits. It helps determine the different preferences of forest visitors. These different preferences can help determine the proper target market. Understanding recreation trends and research on this topic has been an important aspect of forest policy development worldwide. In 2006, researchers analyzed social change on the Monongahela National Forest (Siniscalchi, Pierskalla, Selin, \& Palmer, 2006). In their study, they discussed the importance of studying trends and social change: "Many communities in and around national forests are experiencing social change. It is important for public land managers to keep abreast of this change to provide appropriate forest uses while considering resource impacts, conflict management, and potential partnerships with local communities" (Siniscalchi, et at., 2006, p. 71). According to Siniscalchi, et al. (2006), forest managers were able to make important changes to the management plan for the Seneca Rocks/Spruce Knob Recreation Area because of the research done in their study. Predating the study on social change, the management plan had not been revised since 1960. In this study, on the Monongahela National Forest, major world events, activity-based segmentation, and recreation trends are all examined to better understand the Monongahela National Forest and the trends that have occurred from 2009 to 2014 (Siniscalchi, et al., 2006).

Activities are an effective segmentation base (Pesonen \& Tuohino, 2017) and are the key product in adventure travel (Schneider et al., 2006). Unlike motivations, an advantage of activity-based segmentation is that it is stable across different national and cultural contexts (Mumuni \& Mansour, 2014). Activities also serve as a link between travel motivation and destination choice (Cooper et al., 2005). Beritelli and Boksberger (2005) link tourist activities and motivations further supporting the important role activities play in destination marketing. In 
addition, grouping activities into packages through segmentation can provide more convenience for travelers and can increase the desire for specialized activities (Hsieh, O'Leary, \& Morrison, 1992).

Because science is based on the groupings of unique events or objects into similarity classes, "Classification of leisure activities has been and currently remains an essential part of leisure research" (Williams, 1988, p. 153). McCool (1978) defined an activity package as a set of activities that a visiting group engages in at a recreation area. One of the first and best examples of a study on activity type, especially as it relates to forest recreation packages, was conducted by Hendee, Gale, and Catton (1971). Respondents in their study were asked to identify their six most preferred activities from a list of twenty-six conceivable recreation activities. They proposed five conceptually linked activity packages based on "perceived similarities in the underlying meanings of the activities to the participant" (McCool, 1978, p. 166). The typology is unique because it is based on the study of recreationists visiting both car campgrounds and wilderness in national parks and national forests, therefore it is most suitable for our study of National Forest visitors. In addition, the study was among three studies that Manning (2011) selected to illustrate the genre of research on activity type. McCool (1978) added additional examples of activities to the five activity packages which are summarized below (somewhat abbreviated):

- Appreciative-Symbolic: Activities directed toward appreciation of features of the natural environment. The recreationist's focus is on appreciation of material items in the environment rather than on their extraction in the form of "trophies." Examples of activities include seeing natural scenery on foot or horseback, hiking, and photography. 
- Extractive-Symbolic: Activities characterized by the quest for trophies extracted from the natural environment. Examples of activities include fishing and hunting.

- Passive-Free Play: Activities requiring little effort and not confined to the forest environment. Examples of activities include relaxing, driving for pleasure, quiet boating or canoeing, and picnicking.

- Sociable-Learning: Social and learning activities such as nature study, hearing nature talks, visiting exhibits, visiting historic sites, and visiting with other people.

- Active-Expressive: Activities not requiring use of a forest setting and which, in fact, sometimes interfere with other activities at the same site. Examples of activities include swimming, jogging, bicycling, golf, and organized games such as playing softball, football, and horseshoes.

The travel industry is constantly changing and the internet has become an indispensable channel for travelers to seek travel information (Beldona, Morrison, \& O’Leary, 2005). This provides a cost effective, easily accessible marketplace for travel agencies and travelers. Ryu, Choi, and Cho (2018) conducted a study investigating how different types of travelers use peerto-peer online travel marketplaces in distinctive ways. The peer-to-peer online travel marketplace serves as a connector between tourists and local suppliers for things like accommodations (e.g. Airbnb) and tours (e.g. Triip) (Ryu, et al., 2018). They assessed different traveler behaviors and measured them using six factors from twenty items. A total of 2,467 survey respondents were combined with real transaction data. The respondents were put into six groups based on several aspects, such as demographic characteristics (Ryu, et al., 2018). This study found that the travelers' online usage was very different and provided insights on the importance of understanding the interests of different travelers, especially for marketplace operators and 
tourism businesses. Placing respondents into specific clusters provided information that shows tourism businesses should not only chase potential visitors but also choose the advertisements most suitable to their characteristics. Understanding visitor characteristics is important for satisfying different visitor types (Ryu, et al., 2018).

Our study used market segmentation, particularly activity-based segmentation, to create activity packages that can be compared with Hendee, Gale, and Catton's (1971) typology. Researchers examining activity participation have been aware of the activity package concept, but studies tend to primarily use empirical methodologies rather than the development of conceptual frameworks (McCool, 1978). Few, if any, recent studies have directly compared their activity groupings with an activity-based segmentation framework. This is a gap in the literature that is addressed by this thesis.

Activity-based segmentation has proved useful for many different types of tourists and has a wide array of support. Schneider et al. (2006) cited a range of studies that use activity-based segmentation including segmentation for culture tourists (McKercher, Ho, du Cros, \& So-Ming, 2002), nature tourists (Lang \& O'Leary, 1997), ecotourists (Wight, 1996), adventure tourists (Sung, Morrison \& O'Leary, 1997), and visiting friends and relatives tourist market (Moscardo, Pearce, Morrison, Green, \& O'Leary, 2000). Support for activity-based segmentation can also be found throughout the world. We compiled studies that have been published since 2006 (Table 1). 
Table 1

Activity segmentation literature updated from Schneider, Vogt, and Smith (2006).

\begin{tabular}{|c|c|c|c|}
\hline Author & Date & Sample & Name of Segments \\
\hline $\begin{array}{l}\text { Schneider, Vogt, \& } \\
\text { Smith }\end{array}$ & 2006 & US adventure travel market & $\begin{array}{ll}\text { - } & \text { Soft nature } \\
\text { - } & \text { Cerebral Pursuit } \\
\text { - } & \text { Question marks } \\
\text { - } & \text { Expedition discovery }\end{array}$ \\
\hline $\begin{array}{l}\text { Choi, Murraya, \& } \\
\text { Kwana }\end{array}$ & 2011 & $\begin{array}{l}\text { Canadian domestic } \\
\text { pleasure travelers to New } \\
\text { Brunswick }\end{array}$ & $\begin{array}{ll}\text { - } & \text { Outdoor lovers } \\
\text { - } & \text { Active explorers } \\
\text { - } & \text { Cultural shoppers }\end{array}$ \\
\hline Boekstein \& Spencer & 2013 & $\begin{array}{l}\text { Thermal spring resorts in } \\
\text { South Africa }\end{array}$ & $\begin{array}{ll}\text { - } & \text { Passive families } \\
\text { - } & \text { Passive relaxers } \\
\text { - } & \text { Active outdoors } \\
\text { - } & \text { Active families } \\
\end{array}$ \\
\hline Mumuni \& Mansour & 2014 & $\begin{array}{l}\text { Saudi Arabia's outbound } \\
\text { leisure tourism market }\end{array}$ & $\begin{array}{ll}\text { - } & \text { Conservatives } \\
\text { - } & \text { Variety seekers } \\
\text { - } & \text { Fun seekers } \\
\end{array}$ \\
\hline $\begin{array}{l}\text { Tkaczynski Rundle- } \\
\text { Thiele, \& Prebensen }\end{array}$ & 2015 & $\begin{array}{l}\text { Norway's nature-based } \\
\text { tourists based on summer, } \\
\text { winter, and year-round } \\
\text { activity preferences }\end{array}$ & $\begin{array}{l}\text { - Experiencing the midnight } \\
\text { sun (summer) } \\
\text { - Experiencing the northern } \\
\text { lights (winter) } \\
\text { - Experiencing fjords (year- } \\
\text { round) }\end{array}$ \\
\hline $\begin{array}{l}\text { Barić, Anić, \& } \\
\text { Bedoya }\end{array}$ & 2016 & $\begin{array}{l}\text { Croatia's protected area } \\
\text { visitors }\end{array}$ & $\begin{array}{ll}\text { - } & \text { Activists } \\
\text { - } & \text { Passivists }\end{array}$ \\
\hline Pesonen \& Tuohino & 2017 & $\begin{array}{l}\text { Finland's rural well-being } \\
\text { tourists }\end{array}$ & $\begin{array}{ll}\text { - } & \text { Sporties } \\
\text { - } & \text { Wellbeing enthusiasts } \\
\text { - } & \text { Spa goers } \\
\end{array}$ \\
\hline $\begin{array}{l}\text { Eusébio, Carneiro, } \\
\text { Kastenholz, } \\
\text { Figueiredo, \& da } \\
\text { Silva }\end{array}$ & 2017 & $\begin{array}{l}\text { Portugal's domestic rural } \\
\text { tourism market }\end{array}$ & 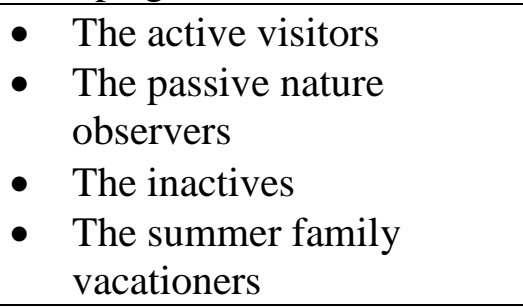 \\
\hline
\end{tabular}


Table 1 lists a variety of studies specializing in activity-based segmentation. The studies listed occurred from 2006-2017 in various countries throughout the world. The following will provide detail on the studies listed in Table 1.

In 2006, Schneider, Vogt, and Smith conducted a study analyzing activities associated with the adventure travel category. More specifically, the purpose of their study was to find out if consumers associated a specific group of activities with adventure travel and determine if there were any sub-groupings of these activities. The data for this study were collected with the use of self-administered surveys of visitors attending travel trade shows in Chicago, New York, and Washington, D.C. There were 27 activities included in the adventure travel category for this study. Respondents were asked their level of agreement with the inclusion of the activities on a five-point scale ( $1=$ strongly agree to $5=$ strongly disagree). Mountain climbing showed the highest (Mean=1.65, SD .728) and hunting the lowest level of agreement (Mean=2.75, SD 1.32) (Schneider et al., 2006). Certain activities are more associated with adventure travel than others, but the range of activities that make up adventure travel are infinite because of adventure's subjective nature (Schneider et al., 2006). This information can assist tourism businesses in determining their effective target markets.

In New Brunswick, Canada one of their main economic generators is tourism. In 2006 tourism revenue reached $\$ 1.2$ billion with 1.57 million visitors. Around $73 \%$ of New Brunswick's visitors were non-residents. New Brunswick's tourism industry still faces challenges like seasonality, awareness, product diversification, and short length of stay (Choi, Murraya, \& Kwana, 2011). The study conducted by Choi, Murraya, and Kwana (2011) segments current and potential visitors by using activity as a segmentation base. The survey for this study 
collected information on sociodemographic variables including age, income, education, occupation, marital status, gender, ethnicity, benefits sought, activity participation, information sources for trip planning, past trip experience to New Brunswick, total number of days stayed, travel satisfaction, likelihood to visit New Brunswick, and the reasons for domestic travelers' overnight trips to any destination over the past 2 years within Canada. Based on the survey results, three clusters were used to describe the respondents. Cluster 1 ( $31 \%$ of the sample) was labeled outdoor lovers, Cluster 2 (37\% of the sample) was labeled active explorers, and Cluster 3 (32\% of the sample) was labeled cultural shoppers. The results from the study show significant differences between the three clusters. Outdoor lovers and active explorers stated that their major reasons for traveling to New Brunswick were vacation and getaway and to visit specific attractions. Cultural shoppers traveled to New Brunswick to visit specific attractions, to have a vacation or getaway, and to visit family and friends.

In the Western Cape providence of South Africa there are eight thermal spring resorts that offer wellness treatments and therapies (Boekstein \& Spencer, 2013). In the past, these resorts have been used for medicinal purposes but are now primarily used as family leisure resorts. A questionnaire of 32 common thermal spring activities was distributed throughout six resorts in the Western Cape. Using a 1 to 5 Likert scale, visitors were asked to decide how important each activity was to themselves and their families. The questionnaires' list included activities that were currently available through at least one of the resorts and activities unavailable at all of the resorts. The results from the questionnaires were used to conduct cluster analysis and market segmentation. The ratings of the 32 activities varied from 1 (Not at all important) to 5 (Very important). The means of each activity was high enough to show at least some support for these activities. The respondents were divided into four activity-based clusters: Passive Families (28\% 
of respondents), Passive Relaxers (23\% of respondents), Active Outdoors (22\% of respondents), and Active Families (27\% of respondents). Using market segmentation of visitors provides insights into more specific groups interested in health tourism that were not well known before. For example, cluster 4 (Active Families) showed a strong interest in wellness activities and water-based medical treatments. The other three clusters showed less interest in organized health activities.

The Kingdom of Saudi Arabia accounts for around $40 \%$ of all outbound tourists in the region, making it the largest in the Middle East (Mumuni \& Mansour, 2014). Each year approximately $49.7 \%$ of its residents travel for leisure, $20.9 \%$ travel for business, $21.5 \%$ travel to visit friends and relatives, and 7.9\% travel for medical purposes. Researchers Mumuni and Mansour (2014) conducted a study to determine if the outbound Saudi leisure travel market can be segmented on the basis of activities that are popular with tourist participation. This study provided insight for tourism markets to better develop marketing plans and gave a better understanding of the behavior of Saudi vacation tourists. This study was conducted using a self-administered questionnaire focusing on several issues like vacation preferences and factors influencing destination choices. Results from this study showed three main segments of outbound tourists from Saudi Arabia: conservatives, fun seekers, and variety seekers. The segments showed different sociodemographic profiles and vacation preferences (Mumuni \& Mansour, 2014). The conservative segment showed dislike for entertainment oriented activities like night clubs and movies. This segment made up $41 \%$ of the sample and was primarily made up of older, married male respondents. Fun seekers favored shopping and fun related activities like amusement parks and made up $25 \%$ of the sample. This group was made up of primarily young, single female 
respondents. Variety seekers made up 34\% of the sample and showed interest in all of the included vacation activities.

Another study using activity-based segmentation was conducted by researchers in Norway, "Despite significant research into seasonality and nature-based activity preferences, academic researchers are not profiling activity-oriented tourists into segments based on temporal factors such as seasons" (Tkaczynski, Rundle-Thiele, \& Prebensen, 2015, p. 251). Tkaczynski, et al. (2015) classified 8,962 nature-based tourists activities collected from a Norwegian questionnaire. Respondents were segmented based on their summer, winter, and year-round activities. For this study, four clusters were identified after the respondent's seasonality was taken into account. In this case, activity-based segmentation allowed researchers to discover that "preferred activities represent a driver of tourism to many seasonal destinations" (Tkaczynski, et al., 2015, p. 260). Results showed that the preferred activities for the seasons all pertained to sight-seeing: "experiencing the midnight sun (summer)," "experiencing the northern lights (winter)," and "experiencing fjords (year-round)". Understanding the preferred activities based on seasonal preferences allows tourism businesses to better meet the needs of their target market.

A study focusing on activity-based segmentation of specific visitor subgroups was conducted in Paklenica National Park, Croatia. The purpose of this study was to demonstrate the utility and practical application of activity-based visitor segmentation in protected areas. For this study, visitors were administered a face-to-face questionnaire. The questionnaire was made up of three main parts focusing on importance of activities, importance of benefits, and travel behavior. After a cluster analysis was conducted two clusters were deemed appropriate. The first cluster (Activists) made up $60.8 \%$ of the sample and was compromised of visitors exclusively there for 
rock climbing and showed little to no interest in other recreational activities. The second cluster (Passivists) participated in more, but less challenging, activities. The results from this study showed that visitors to wilderness and protected natural areas are not a homogenous group (Barić, Anić, \& Bedoya, 2016). These results may assist park managers to develop strategies to improve physical, social, and managerial setting characteristics. Doing so would increase opportunities for targeted groups to attain desired benefits (Barić et al., 2016).

Wellness tourism is becoming increasingly popular in the travel and tourism industry. A study conducted by Pesonen and Tuohino (2017) focuses on segmenting wellbeing tourists based on their wellbeing activity preferences to assist tourism businesses, more specifically Finnish companies specializing in rural tourism. For this study, an online questionnaire was placed on the largest Finnish website for rural tourism as well as two smaller websites. To increase the response rate a $500 €$ gift certificate was given to one respondent as a prize (Pesonen \& Tuohino, 2017). The questionnaire focused on information channels and socio-demographic factors. The results from this study found that three clusters best described the respondents. The three clusters were labeled Sporties, Wellbeing Enthusiasts and Spa Goers. Wellbeing Enthusiasts regarded travel motivations as being more important than the other clusters, while Sporties found the opportunity to be physically active more important. There was not much difference between the segments regarding information channels. All participants stated the internet was the most important information channel. The results from this study show that Wellbeing Enthusiasts can be reached using travel magazines and travel agencies easier than the other two segments. This study provided insight on the most efficient ways to target various activity segments by examining how people use various electronic information channels. 


\section{Trend Studies}

The preferred outdoor activities of visitors are different now from what they were in the past. Activities that were thought to be popular years ago like hunting and fishing are being replaced with activities like bird watching and photography (Ordell, 2012). Throughout history, the Forest Service and Department of Agriculture have conducted trend studies on public lands in America. The purpose of these studies is to gain a better understanding of current outdoor recreation participation patterns as well as to compare patterns across different regions (Ordell, 2012). With the use of trend studies, researchers are able to discover present past trends in outdoor recreation, current outdoor recreation participation patterns and trends, recreation participation patterns across regional and demographic strata, recreation activity participation on public and private lands, projections of outdoor recreation participation in the future, and highlight departures from past patterns to indicate potential public and private sector implications (Ordell, 2012). Several approaches can be employed to conduct trend studies such as the examination of previous and current data as well as reviewing past studies conducted by research experts in the field of outdoor recreation.

\section{Satisfaction}

Nature based tourism is a significant sector of the tourism industry (Naidoo, RamseookMunhurrun, \& Seegoolam, 2011). Because of this significance, research on visitor satisfaction is important for both visitors and tourism businesses. Analysis on visitor satisfaction gives tourism providers the opportunity to assess the strong and weak attributes of the destination which in turn helps to improve the overall quality of the destination (Naidoo, et al., 2011). There have been several studies on visitor satisfaction in the nature-based tourism industry. Naidoo, et al. (2011) 
conducted a quantitative study on the island of Mauritius that assessed the satisfaction of 600 visitors. The questionnaire for this study was divided into four sections: questions regarding satisfaction, overall satisfaction and customer loyalty, open and close-ended questions, and questions collecting demographic information of the visitors. Having the four different sections allowed researchers to evaluate visitor experiences, allow respondents to express their general attitudes that assist in interpreting the general questions, and gain an overall better understanding of the destination's visitors (Naidoo, et al., 2011). The results from this study showed multiple key findings. It was found that visitors felt that staff was not well informed to react to consumers requests (Naidoo, et al., 2011). The study also discovered that there is a relationship between nature based tourism attractions, overall satisfaction, and visitors' loyalty intentions (Naidoo, et al., 2011). This shows that several factors such as price, assurance, empathy, and natural resources have a significant role in visitor satisfaction (Naidoo, et al., 2011).

There have also been studies that have identified factors determining the satisfaction of outdoor recreation participants (Nowacki, 2012). Determining these factors assists in the development of the outdoor recreation satisfaction model (Nowacki, 2012). The model for satisfaction in outdoor recreation has been divided into two groups of factors: situational and subjective evaluation (Nowacki, 2012). Situational satisfaction includes resource and environment conditions, social settings and management settings. Subjective evaluation consists of socioeconomic characteristics, attitudes and preferences, cultural characteristics, subjective norms, experience, crowding and risk perception. When considering the two groups of factors in the satisfaction model, there are other variables out of the control of recreation managers that should also be considered such as weather or the mood of a visitor triggered by other factors. The large number of uncontrollable variables determining the satisfaction of outdoor recreation tend 
to play a role in overall satisfaction levels and outdoor recreation participants satisfaction often remains high (Nowacki, 2012). When measuring satisfaction, it is beneficial to focus on the satisfaction of individual service components and specific scenarios or experiences.

Market segmentation, activity-based segmentation, trend studies, and satisfaction all play an important role in understanding recreation activity participation and the role of the 2008-2009 financial crisis on the Monongahela National Forest. When considered together, these topics provide valuable insight to this study. Previous literature was used to assess recreational activity in the past as well as to develop a framework for this study. 


\section{Method}

The purpose of this study is to take results from visitor use surveys and analyze recreation activity participation over five years, especially following the world financial crisis of 20082009. This section will focus on the study instrument, sampling method, and data analysis.

In order to obtain the data for this research, National Visitor Use Monitoring (NVUM) surveys from 2009 and 2014 were examined. The study was conducted on the Monongahela National Forest which is located in the Allegheny Mountains of eastern West Virginia. The Forest consists of over 921,000 acres of federally owned land. Tourism is an increasingly important part of the West Virginia economy given the volatility of the coal mining industry.

We used data that we helped collect for the National Visitor Use Monitoring (NVUM) program of the US Forest Service. The objective of the NVUM program is to estimate the volume of recreation visitation to all National Forests and Grasslands in the US and to analyze visitation with respect to activity participation, demographics, trip spending, travel distance, etc. The revised method was first applied in 2000. The 12-month studies are conducted on a 5-year sampling cycle in each National Forest in the U.S. 


\section{Study Instrument}

NVUM interviews are conducted onsite and collect immediate information after a visit. NVUM surveys consist of three major section variations: general module, economics module, and satisfaction module (Askew, Bowker, English, Zarnoch, \& Green, 2017). The three major questionnaire variations are explained in Table 2. Each person surveyed was asked the general questions (demographics, participation in recreational activities, and duration of stay) while economics and satisfaction questions were asked as a subset to the general questions. Appendices A-F list the questions asked on each survey form.

\section{Table 2}

Description of NVUM Survey Forms

\begin{tabular}{|c|c|}
\hline Form Type & Description of Form \\
\hline General & $\begin{array}{l}\text { Focuses on visitor demographics, participation in various recreational } \\
\text { activities, distance traveled, and nights away from home. }\end{array}$ \\
\hline Satisfaction & $\begin{array}{l}\text { All questions from the general form are included along with an extra } \\
\text { page asking questions pertaining to visitor satisfaction. A set of } 14 \\
\text { recreation services and facilities are listed with a 1-5 scale where } 1 \\
\text { means very dissatisfied and } 5 \text { means very satisfied. Questions on } \\
\text { crowding and accessibility are also included. }\end{array}$ \\
\hline Economics & $\begin{array}{l}\text { All questions from the general form are included along with an extra } \\
\text { page asking a set of questions focusing on trip expenditure. Questions } \\
\text { include trip expenditure of } 10 \text { specific spending categories, total trip } \\
\text { spending, and annual household income. This section also includes } \\
\text { questions on the use of special areas and facilities as well as what the } \\
\text { visitor might have done instead of coming to the Forest. }\end{array}$ \\
\hline
\end{tabular}




\section{Sampling}

The stratified random sampling method was used for NVUM survey locations and times and includes four site types. Surveyors conducted interviews at designated locations with the intention of contacting as many exiting groups as possible. Only the visitors that were leaving the survey site were interviewed. No visitors that were entering the location or actively recreating were interviewed. The four site types for surveying include day-use developed sites (DUDS),

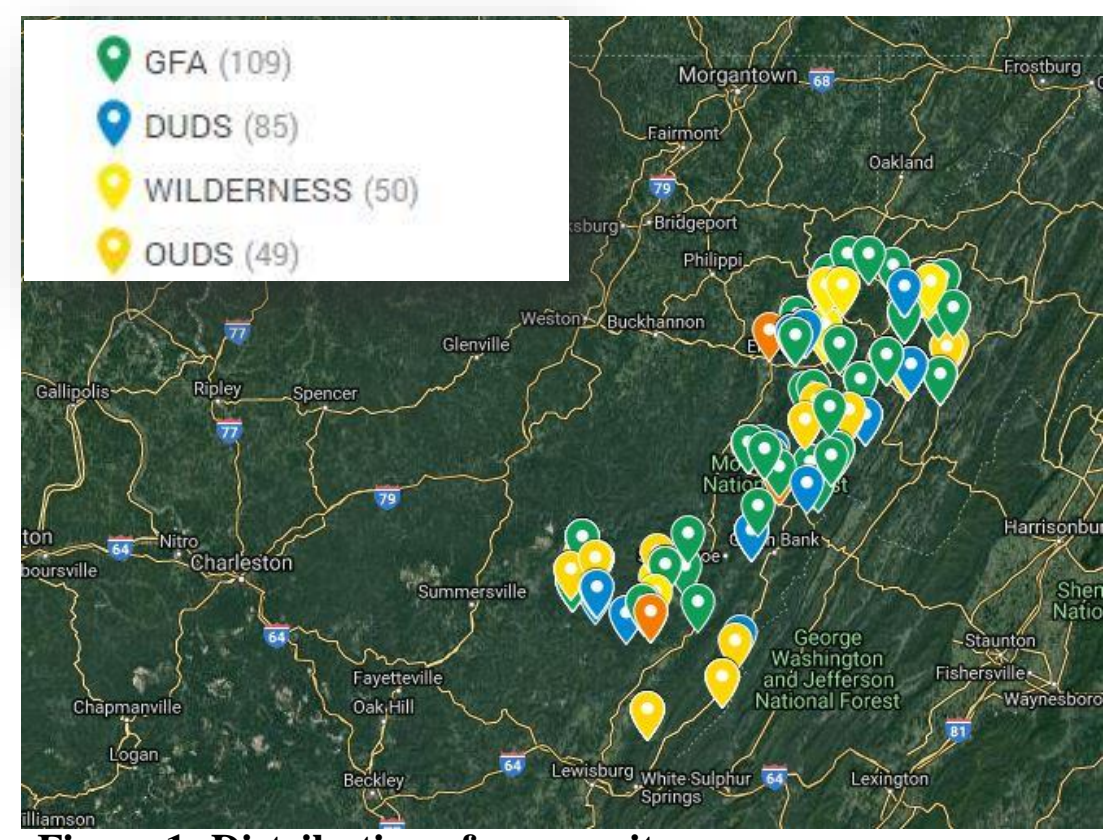

Figure 1: Distribution of survey sites general forest area (GFA),

overnight-use developed sites

(OUDS), and designated Wilderness

(WILD). DUDS and OUDS visitors

typically recreate in facilities

developed for the national forest

including picnic areas,

campgrounds, cabins, lodges, or

developed fishing areas. Any area

under the jurisdiction of the National

Wilderness Preservation System is considered WILD (Askew, Bowker, English, Zarnoch, \& Green, 2017). GFA areas include any undeveloped forest land that is not WILD, DUDS, or OUDS such as forest roads, trails, rivers, and lakes. Dispersion of survey sites throughout the forest can be seen in Figure 1. 


\section{Data Analysis}

This thesis includes seven research questions that were used to examine visitor use surveys and recreation activity participation throughout those five years, especially following the world financial crisis of 2008-2009. The seven research questions are:

- How has recreation participation changed over five years on the Monongahela National Forest following the world financial crisis in fiscal year 2009?

- What are the activity-based market segments?

- For each market segment, is there a difference in visitor demographics for fiscal years 2009 and $2014 ?$

- What are the main and interaction effects of fiscal year and cluster membership on travel distance, trip expenditures, nights away from home, and overall satisfaction?

- Was the "global economic downturn" ubiquitous across all market segments?

- Are the 5 activity packages proposed by Hendee, Gale, and Cotton (1971) represented on the Monongahela National Forest?

- How much activity variety exists within each activity package on the Monongahela National Forest?

To answer these questions data were analyzed using IBM SPSS Statistics Version 25. Twostep cluster analysis of 18 activity participation variables (binary "yes" or "no" data) were conducted with 3 to 5 clusters examined to find the most logical solution for the entire data set. Two-way analysis of variance (ANOVA) was used to examine two categorical independent 
variables (i.e., fiscal year of study and cluster membership) and one continuous dependent variable (i.e., travel distance, trip spending, nights away from home, and overall satisfaction). We compared the association between activity participation, primary activity, cluster membership, and demographics with fiscal year using Chi-square tests. 


\section{Results}

\section{Segmentation Procedure}

The sample size was 823 visitors in fiscal year 2009 and 1,028 in fiscal year 2014. A two-step cluster analysis was used to segment visitors to the Monongahela National Forest using all of the data collected during both years. That is, visitors who participated in similar activities were grouped together. Based on criteria provided by Weinstein (1987), a five-cluster solution was selected. The criteria include homogeneity within the segment, heterogeneity between segments, sizable population, and meaningful segment data (e.g., segment data that is most practical and usable). Each cluster was given a name based on the package of activities and the primary activities reflected in the cluster. The five clusters found were: 1) Relaxing in Nature Package, 2) Backpacking and Hiking Package, 3) Viewing Nature and Hunting Package, 4) Picnicking Package, and 5) Purely Fishing.

\section{Relaxing in Nature Package}

Cluster $1(n=577)$ represented 31.2 percent of the total sample in this study and was labeled Relaxing in Nature Package (Table 3). The activity of viewing nature had the highest percentage of visitors (95\%) within the cluster. The percentages associated with activity participation that were among the highest across clusters include hiking $(82 \%)$, relaxing $(81.8 \%)$, viewing wildlife (80.8\%), driving for pleasure (67.8\%), nature centers (50.8\%), history (35.4\%), nature study (25.6\%), and resorts (9.4\%). Visitors were also asked to select their one primary activity among the list of activities. The most common primary activities complement activity participation (Table 4). 


\section{Backpacking and Hiking Package}

Cluster $2(n=296)$ consisted of 16 percent of the total sample and was labeled Backpacking and Hiking Package (Table 3). Most respondents participated in hiking (78\%). Other activities include viewing wildlife (65.2\%) and backpacking (50\%), and both reflect the highest percentages across clusters. The selection of a primary activity complements these findings (Table 4).

\section{Viewing Nature and Hunting Package}

Cluster $3(n=483)$ represented 26.1 percent of the sample and was labeled Viewing Nature and Hunting Package. Compared to other clusters, hunting participation (7\%) was highest for this cluster (Table 3 ). Viewing nature was also selected as the primary activity (25.3\%) more often than the other four clusters (Table 4).

\section{Picnicking Package}

Cluster $4(n=252)$ represented 13.6 percent of the sample and was labeled Picnicking Package. Participation in picnicking (50.8\%) along with picnicking as a primary activity (13.9\%) was highest for this cluster (Tables 3 and 4). Hiking participation (70.6\%), developed camping (33.3\%), and biking (16.7\%) were also among the highest percentages across clusters.

\section{Purely Fishing}

Cluster $5(n=242)$ represented 13.1 percent of the sample and was labeled Purely Fishing. This cluster represents visitors who exclusively participate in fishing (99.6\%) and selected fishing as the primary activity (88\%) (Tables 3 and 4$)$. 
Table 3

Activity participation by cluster membership.

\begin{tabular}{|c|c|c|c|c|c|c|}
\hline Activity & $\begin{array}{l}\text { Cluster } 1 \\
(\mathrm{n}=577)\end{array}$ & $\begin{array}{l}\text { Cluster } 2 \\
(\mathrm{n}=296)\end{array}$ & $\begin{array}{l}\text { Cluster } 3 \\
(\mathrm{n}=483)\end{array}$ & $\begin{array}{l}\text { Cluster } 4 \\
(n=252)\end{array}$ & $\begin{array}{l}\text { Cluster } 5 \\
(\mathrm{n}=242)\end{array}$ & $\chi^{2}$ \\
\hline Backpacking & $60(10.4 \%)$ & $148(50 \%)$ & $4(.8 \%)$ & $13(5.2 \%)$ & $1(.4 \%)$ & $497.381 * * *$ \\
\hline Biking & $51(8.8 \%)$ & $0(0 \%)$ & $5(1 \%)$ & $42(16.7 \%)$ & $10(4.1 \%)$ & $103.109 * * *$ \\
\hline Developed Camping & $165(28.6 \%)$ & $24(8.1 \%)$ & $37(7.7 \%)$ & $84(33.3 \%)$ & $70(28.9 \%)$ & $135.76 * * *$ \\
\hline Driving for Pleasure & $391(67.8 \%)$ & $31(10.5 \%)$ & $76(15.7 \%)$ & $70(27.8 \%)$ & $17(7 \%)$ & $535.63 * * *$ \\
\hline Fishing & $104(18 \%)$ & $28(9.5 \%)$ & $0(0 \%)$ & $145(57.5 \%)$ & $241(99.6 \%)$ & $991.025 * * *$ \\
\hline Gathering Mushrooms etc. & $98(17 \%)$ & $82(27.7 \%)$ & $12(2.5 \%)$ & $39(15.5 \%)$ & $6(2.5 \%)$ & $138.607 * * *$ \\
\hline Relaxing & $472(81.8 \%)$ & $161(54.4 \%)$ & $63(13 \%)$ & $171(67.9 \%)$ & $24(9.9 \%)$ & $685.674 * * *$ \\
\hline Hiking & $473(82 \%)$ & $231(78 \%)$ & $122(25.3 \%)$ & $178(70.6 \%)$ & $0(0 \%)$ & $724.046 * * *$ \\
\hline History & $204(35.4 \%)$ & $2(.7 \%)$ & $6(1.2 \%)$ & $3(1.2 \%)$ & $0(0 \%)$ & $460.15^{* * *}$ \\
\hline Hunting & $6(1 \%)$ & $4(1.4 \%)$ & $34(7 \%)$ & $6(2.4 \%)$ & $3(1.2 \%)$ & $42.098 * * *$ \\
\hline Nature Centers & $293(50.8 \%)$ & $0(0 \%)$ & $33(6.3 \%)$ & $6(2.4 \%)$ & $1(.4 \%)$ & $618.203 * * *$ \\
\hline Nature Study & $148(25.6 \%)$ & $13(4.4 \%)$ & $3(.6 \%)$ & $7(2.8 \%)$ & $0(0 \%)$ & $273.457 * * *$ \\
\hline Non-Motorized Water & $22(3.8 \%)$ & $0(0 \%)$ & $1(.2 \%)$ & $8(3.2 \%)$ & $0(0 \%)$ & $34.924 * * *$ \\
\hline Picnicking & $220(38.1 \%)$ & $6(2 \%)$ & $5(1 \%)$ & $128(50.8 \%)$ & $0(0 \%)$ & $507.72 * * *$ \\
\hline Primitive Camping & $66(11.4 \%)$ & $13(4.4 \%)$ & $0(0 \%)$ & $33(13.1 \%)$ & $21(8.7 \%)$ & $70.477 * * *$ \\
\hline Resorts & $54(9.4 \%)$ & $9(3 \%)$ & $7(1.4 \%)$ & $0(0 \%)$ & $2(.8 \%)$ & $70.666 * * *$ \\
\hline Viewing Nature & $548(95 \%)$ & $213(72 \%)$ & $181(37.5 \%)$ & $39(15.5 \%)$ & $0(0 \%)$ & $912.946 * * *$ \\
\hline Viewing Wildlife & $466(80.8 \%)$ & $193(65.2 \%)$ & $2(.4 \%)$ & $41(16.3 \%)$ & $0(0 \%)$ & $1029.826 * * *$ \\
\hline
\end{tabular}

Notes. $* p<0.05 ; * * p<0.01 ; * * * p<0.001$.

Cluster 1: Relaxing in Nature Package; Cluster 2: Backpacking and Hiking Package; Cluster 3: Viewing Nature and Hunting Package;

Cluster 4: Picnicking Package; Cluster 5: Purely Fishing 
Table 4

Primary activity participation by cluster membership.

\begin{tabular}{|c|c|c|c|c|c|c|}
\hline Activity & $\begin{array}{l}\text { Cluster 1 } \\
(\mathrm{n}=577)\end{array}$ & $\begin{array}{l}\text { Cluster } 2 \\
(\mathrm{n}=296)\end{array}$ & $\begin{array}{l}\text { Cluster } 3 \\
(\mathrm{n}=483)\end{array}$ & $\begin{array}{l}\text { Cluster } 4 \\
(\mathrm{n}=252)\end{array}$ & $\begin{array}{l}\text { Cluster } 5 \\
(\mathrm{n}=242)\end{array}$ & $\chi^{2}$ \\
\hline Backpacking & $20(3.5 \%)$ & $86(29.1 \%)$ & $4(.8 \%)$ & $7(2.8 \%)$ & $0(0 \%)$ & $312.403 * * *$ \\
\hline Biking & $6(1 \%)$ & $0(0 \%)$ & $3(.6 \%)$ & $6(2.4 \%)$ & $0(0 \%)$ & $12.715^{*}$ \\
\hline Developed Camping & $28(4.9 \%)$ & $5(1.7 \%)$ & $21(4.3 \%)$ & $29(11.5 \%)$ & $23(9.5 \%)$ & $33.435 * * *$ \\
\hline Driving for Pleasure & $43(7.5 \%)$ & $5(1.7 \%)$ & $40(8.3 \%)$ & $8(3.2 \%)$ & $1(.4 \%)$ & $35.701 * * *$ \\
\hline Fishing & $43(7.5 \%)$ & $19(6.4 \%)$ & $0(0 \%)$ & $82(32.5 \%)$ & $213(88 \%)$ & $961.191 * * *$ \\
\hline Gathering mushrooms, etc. & $1(.2 \%)$ & $3(1 \%)$ & $11(2.3 \%)$ & $3(1.2 \%)$ & $0(0 \%)$ & $14.866 * * *$ \\
\hline Relaxing & $64(11.1 \%)$ & $11(3.7 \%)$ & $17(3.5 \%)$ & $26(10.3 \%)$ & $3(1.2 \%)$ & $47.631 * * *$ \\
\hline Hiking & $146(25.3 \%)$ & $107(36.1 \%)$ & $69(14.3 \%)$ & $21(8.3 \%)$ & $0(0 \%)$ & $156.492 * * *$ \\
\hline History & $7(1.2 \%)$ & $1(.3 \%)$ & $2(.4 \%)$ & $0(0 \%)$ & $0(0 \%)$ & 7.91 \\
\hline Hunting & $2(.3 \%)$ & $2(.7 \%)$ & $32(6.6 \%)$ & $4(1.6 \%)$ & $3(1.2 \%)$ & $54.695 * * *$ \\
\hline Nature Centers & $1(.2 \%)$ & $0(0 \%)$ & $14(2.9 \%)$ & $0(0 \%)$ & $0(0 \%)$ & $31.786 * * *$ \\
\hline Nature Study & $5(.9 \%)$ & $0(0 \%)$ & $1(.2 \%)$ & $0(0 \%)$ & $0(0 \%)$ & 8.024 \\
\hline Non-Motorized Water & $6(1 \%)$ & $0(0 \%)$ & $5(1 \%)$ & $3(1.2 \%)$ & $0(0 \%)$ & 5.848 \\
\hline Picnicking & $23(4 \%)$ & $0(0 \%)$ & $2(.4 \%)$ & $35(13.9 \%)$ & $0(0 \%)$ & $122.377 * * *$ \\
\hline Primitive Camping & $9(1.6 \%)$ & $1(.3 \%)$ & $0(0 \%)$ & $12(4.8 \%)$ & $3(1.2 \%)$ & $31.096^{* * *}$ \\
\hline Resorts & $2(.3 \%)$ & $0(0 \%)$ & $0(0 \%)$ & $0(0 \%)$ & $0(0 \%)$ & 4.417 \\
\hline Viewing Nature & $91(15.8 \%)$ & $19(6.4 \%)$ & $122(25.3 \%)$ & $2(.8 \%)$ & $0(0 \%)$ & $152.1 * * *$ \\
\hline Viewing Wildlife & $24(4.2 \%)$ & $10(3.4 \%)$ & $2(.4 \%)$ & $0(0 \%)$ & $0(0 \%)$ & $33.743 * * *$ \\
\hline
\end{tabular}

Cluster 1: Relaxing in Nature Package; Cluster 2: Backpacking and Hiking Package; Cluster 3: Viewing Nature and Hunting Package;

Cluster 4: Picnicking Package; Cluster 5: Purely Fishing 


\section{Fiscal Year Differences in Cluster Membership}

There were significant winners and losers among the different market segments following the global financial crisis $\left(\chi^{2}=89.4, p<.001\right)$ (Table 5). Visitors participating in the Relaxing in Nature Package were 13.9 percent higher in fiscal year 2009. Participation in Backpacking and Hiking participation was 10.6 percent lower in fiscal year 2009 than in fiscal year 2014. Purely Fishing was 8.4\% lower in fiscal year 2009 than in fiscal year 2014. Thus participation in Backpacking and Hiking and Purely Fishing were among the losing market segments during the financial crisis.

\section{Table 5}

Cluster membership by fiscal year (FY).

\begin{tabular}{llll}
\hline Cluster & FY09 & FY14 & $\chi^{2}$ \\
\hline 1 & $320(38.9 \%)$ & $257(25 \%)$ & $89.431^{* * * *}$ \\
2 & $83(10.1 \%)$ & $213(20.7 \%)$ & \\
3 & $236(28.7 \%)$ & $247(24.1 \%)$ & \\
4 & $115(14 \%)$ & $137(13.3 \%)$ & \\
5 & $69(8.4 \%)$ & $173(16.8 \%)$ & \\
\hline
\end{tabular}

Notes. ${ }^{*} p<0.05 ; * * p<0.01 ; * * *<0.001$.

Cluster 1: Relaxing in Nature Package; Cluster 2: Backpacking and Hiking Package; Cluster 3: Viewing Nature and Hunting Package; Cluster 4: Picnicking Package; Cluster 5: Purely Fishing

\section{Fiscal Year Differences in Demographics}

Demographics including gender, age, and household income were compared by fiscal year for each market segment using two-way analysis of variance (Table 6). The only significant difference $\left(\chi^{2}=13.59, p<.05\right)$ among fiscal years was age for the Purely Fishing cluster. There were fewer cluster members for age groups 50-59, 60-69, and 70+ during the financial crisis. 
That is, older anglers may have been unable to participate during fiscal year 2009 due to financial constraints. See Appendix D for demographic questions. 
Table 6

Visitor demographics by fiscal year (FY).

\begin{tabular}{|c|c|c|c|c|}
\hline & & FY09 & FY14 & $\chi^{2}$ \\
\hline \multirow[t]{2}{*}{ Cluster 1} & Male & $207(64.9 \%)$ & $148(57.8 \%)$ & \multirow{2}{*}{3.012} \\
\hline & Female & $112(35.1 \%)$ & $108(42.2 \%)$ & \\
\hline & Under 16 & $2(0.6 \%)$ & $0(0 \%)$ & \multirow[t]{8}{*}{13.798} \\
\hline & $16-19$ & $5(1.6 \%)$ & $0(0 \%)$ & \\
\hline & $20-29$ & $49(15.4 \%)$ & $35(13.7 \%)$ & \\
\hline & $30-39$ & $56(17.6 \%)$ & $49(19.1 \%)$ & \\
\hline & $40-49$ & $59(18.5 \%)$ & $50(19.5 \%)$ & \\
\hline & $50-59$ & $86(27.0 \%)$ & $54(21.1 \%)$ & \\
\hline & $60-69$ & $47(14.7 \%)$ & $43(16.8 \%)$ & \\
\hline & $70+$ & $15(4.7 \%)$ & $25(9.8 \%)$ & \\
\hline & Under $\$ 25,000$ & $12(12.2 \%)$ & $6(9.8 \%)$ & \multirow[t]{6}{*}{11.418} \\
\hline & $\$ 25,000-\$ 49,000$ & $28(28.6 \%)$ & $7(11.5 \%)$ & \\
\hline & $\$ 50,000-\$ 74,000$ & $23(23.5 \%)$ & $17(27.9 \%)$ & \\
\hline & $\$ 75,000$ - $\$ 99,000$ & $15(15.3 \%)$ & $12(19.7 \%)$ & \\
\hline & $\$ 100,000-\$ 149,999$ & $16(16.3 \%)$ & $13(21.3 \%)$ & \\
\hline & $\$ 150,000$ or over & $4(4.1 \%)$ & $6(9.8 \%)$ & \\
\hline \multirow[t]{16}{*}{ Cluster 2} & Male & $65(78.3 \%)$ & $149(70.6 \%)$ & \multirow[t]{2}{*}{1.782} \\
\hline & Female & $18(21.7 \%)$ & $62(29.4 \%)$ & \\
\hline & Under 16 & $1(1.2 \%)$ & $0(0 \%)$ & \multirow[t]{8}{*}{8.207} \\
\hline & $16-19$ & $1(1.2 \%)$ & $0(0 \%)$ & \\
\hline & $20-29$ & $12(14.5 \%)$ & $35(13.6 \%)$ & \\
\hline & $30-39$ & $16(19.3 \%)$ & $49(19.1 \%)$ & \\
\hline & $40-49$ & $18(21.7 \%)$ & $50(19.5 \%)$ & \\
\hline & $50-59$ & $18(21.7 \%)$ & $54(21.0 \%)$ & \\
\hline & $60-69$ & $14(16.9 \%)$ & $43(16.7 \%)$ & \\
\hline & $70+$ & $3(3.6 \%)$ & $25(9.7 \%)$ & \\
\hline & Under $\$ 25,000$ & $2(8.7 \%)$ & $6(10.0 \%)$ & \multirow[t]{6}{*}{0.791} \\
\hline & $\$ 25,000-\$ 49,000$ & $6(26.1 \%)$ & $17(28.3 \%)$ & \\
\hline & $\$ 50,000-\$ 74,000$ & $8(34.8 \%)$ & $16(26.7 \%)$ & \\
\hline & $\$ 75,000-\$ 99,000$ & $3(13.0 \%)$ & $7(11.7 \%)$ & \\
\hline & $\$ 100,000-\$ 149,999$ & $2(8.7 \%)$ & $8(13.3 \%)$ & \\
\hline & $\$ 150,000$ or over & $2(8.7 \%)$ & $6(10.0 \%)$ & \\
\hline
\end{tabular}


Table 6 continued

Visitor demographics by fiscal year (FY).

\begin{tabular}{|c|c|c|c|c|}
\hline & & FY09 & FY14 & $\chi^{2}$ \\
\hline \multirow[t]{16}{*}{ Cluster 3} & Male & $120(65.9 \%)$ & $141(71.6 \%)$ & 1.403 \\
\hline & Female & $62(34.1 \%)$ & $56(28.4 \%)$ & \\
\hline & Under 16 & $5(2.8 \%)$ & $1(0.5 \%)$ & 9.523 \\
\hline & $16-19$ & $3(1.7 \%)$ & $7(3.5 \%)$ & \\
\hline & $20-29$ & $28(15.5 \%)$ & $34(17.2 \%)$ & \\
\hline & $30-39$ & $38(21 \%)$ & $27(13.6 \%)$ & \\
\hline & $40-49$ & $33(18.2 \%)$ & $31(15.7 \%)$ & \\
\hline & $50-59$ & $32(17.7 \%)$ & $44(22.2 \%)$ & \\
\hline & $60-69$ & $27(14.9 \%)$ & $33(16.7 \%)$ & \\
\hline & $70+$ & $15(8.3 \%)$ & $21(10.6 \%)$ & \\
\hline & Under $\$ 25,000$ & $3(5.6 \%)$ & $7(14.3 \%)$ & 5.943 \\
\hline & $\$ 25,000-\$ 49,000$ & $13(24.1 \%)$ & $13(26.5 \%)$ & \\
\hline & $\$ 50,000-\$ 74,000$ & $15(27.8 \%)$ & $12(24.5 \%)$ & \\
\hline & $\$ 75,000-\$ 99,000$ & $9(16.7 \%)$ & $3(6.1 \%)$ & \\
\hline & $\$ 100,000-\$ 149,999$ & $5(9.3 \%)$ & $7(14.3 \%)$ & \\
\hline & $\$ 150,000$ or over & $9(16.7 \%)$ & $7(14.3 \%)$ & \\
\hline \multirow[t]{16}{*}{ Cluster 4} & Male & $77(67.5 \%)$ & $96(70.6 \%)$ & 0.27 \\
\hline & Female & $37(32.5 \%)$ & $40(29.4 \%)$ & \\
\hline & Under 16 & $2(1.7 \%)$ & $0(0 \%)$ & 6.83 \\
\hline & $16-19$ & $8(7.0 \%)$ & $3(2.2 \%)$ & \\
\hline & $20-29$ & $13(11.4 \%)$ & $15(11.0 \%)$ & \\
\hline & $30-39$ & $22(19.3 \%)$ & $31(22.8 \%)$ & \\
\hline & $40-49$ & $24(21.1 \%)$ & $31(22.8 \%)$ & \\
\hline & $50-59$ & $17(14.9 \%)$ & $25(18.4 \%)$ & \\
\hline & $60-69$ & $23(20.2 \%)$ & $24(17.6 \%)$ & \\
\hline & $70+$ & $5(4.4 \%)$ & $7(5.1 \%)$ & \\
\hline & Under $\$ 25,000$ & $5(16.1 \%)$ & $1(3.7 \%)$ & 6.842 \\
\hline & $\$ 25,000-\$ 49,000$ & $8(25.8 \%)$ & $5(18.5 \%)$ & \\
\hline & $\$ 50,000-\$ 74,000$ & $9(29.0 \%)$ & $11(40.7 \%)$ & \\
\hline & $\$ 75,000$ - \$99,000 & $6(19.4 \%)$ & $6(22.2 \%)$ & \\
\hline & $\$ 100,000-\$ 149,999$ & $2(6.5 \%)$ & $4(14.8 \%)$ & \\
\hline & $\$ 150,000$ or over & $1(3.2 \%)$ & $0(0 \%)$ & \\
\hline
\end{tabular}


Table 6 continued

Visitor demographics by fiscal year (FY).

\begin{tabular}{lllll}
\hline & & FY09 & FY14 & $\chi^{2}$ \\
\hline Cluster 5 & Male & $63(91.3 \%)$ & $155(91.2 \%)$ & 0.001 \\
& Female & $6(8.7 \%)$ & $15(8.8 \%)$ & \\
& Under 16 & $0(0 \%)$ & $0(0 \%)$ & $13.59 *$ \\
$16-19$ & $2(2.9 \%)$ & $1(0.6 \%)$ & \\
$20-29$ & $9(13.0 \%)$ & $12(7.0 \%)$ & \\
$30-39$ & $7(10.1 \%)$ & $20(11.7 \%)$ & \\
$40-49$ & $19(27.5 \%)$ & $28(16.4 \%)$ & \\
$50-59$ & $15(21.7 \%)$ & $46(26.9 \%)$ & \\
$60-69$ & $16(23.2 \%)$ & $45(26.3 \%)$ & \\
$70+$ & $1(1.4 \%)$ & $19(11.1 \%)$ & \\
& & & \\
Under $\$ 25,000$ & $3(16.7 \%)$ & $2(6.3 \%)$ & \\
$\$ 25,000-\$ 49,000$ & $6(33.3 \%)$ & $14(43.8 \%)$ & \\
$\$ 50,000-\$ 74,000$ & $3(16.7 \%)$ & $11(34.4 \%)$ & \\
$\$ 75,000-\$ 99,000$ & $4(22.2 \%)$ & $3(9.4 \%)$ & \\
$\$ 100,000-\$ 149,999$ & $1(5.6 \%)$ & $2(6.2 \%)$ & \\
$\$ 150,000$ or over & $1(5.6 \%)$ & $0(0 \%)$ & \\
\hline Notes. $* p<05 ; * *<0.01 ; * * *<<0.001$ & &
\end{tabular}

Cluster 1: Relaxing in Nature Package; Cluster 2: Backpacking and Hiking Package; Cluster 3: Viewing Nature and Hunting Package; Cluster 4: Picnicking Package; Cluster 5: Purely Fishing

\section{Respondent Location by Fiscal Year and Cluster}

Respondents were asked their home zip-code to determine where visitor trips to the Monongahela National Forest originated. The reported zip-codes were transferred to maps for every cluster and fiscal year. Figures 2-9 show respondent locations based on their respective fiscal year and cluster.

The results shown in the respondent location by fiscal year vary based on the market segment. Overall, figures 2-11 show the majority of visitors are from the eastern United States. Cluster 1 shows most visitors are from the region with some visitors throughout other regions of the country in both fiscal years included in the study. Similar results were found in cluster 3 for both 
fiscal years. Cluster 3 also had a majority of visitors in the region surrounding the forest with some visitors spread throughout the country. Clusters 2, 4, and 5 were found to have tighter groupings in visitor zip-codes. Overall, most visitors were shown to be from the general region around the forest with some outliers in cluster 2, fiscal year 2014. 


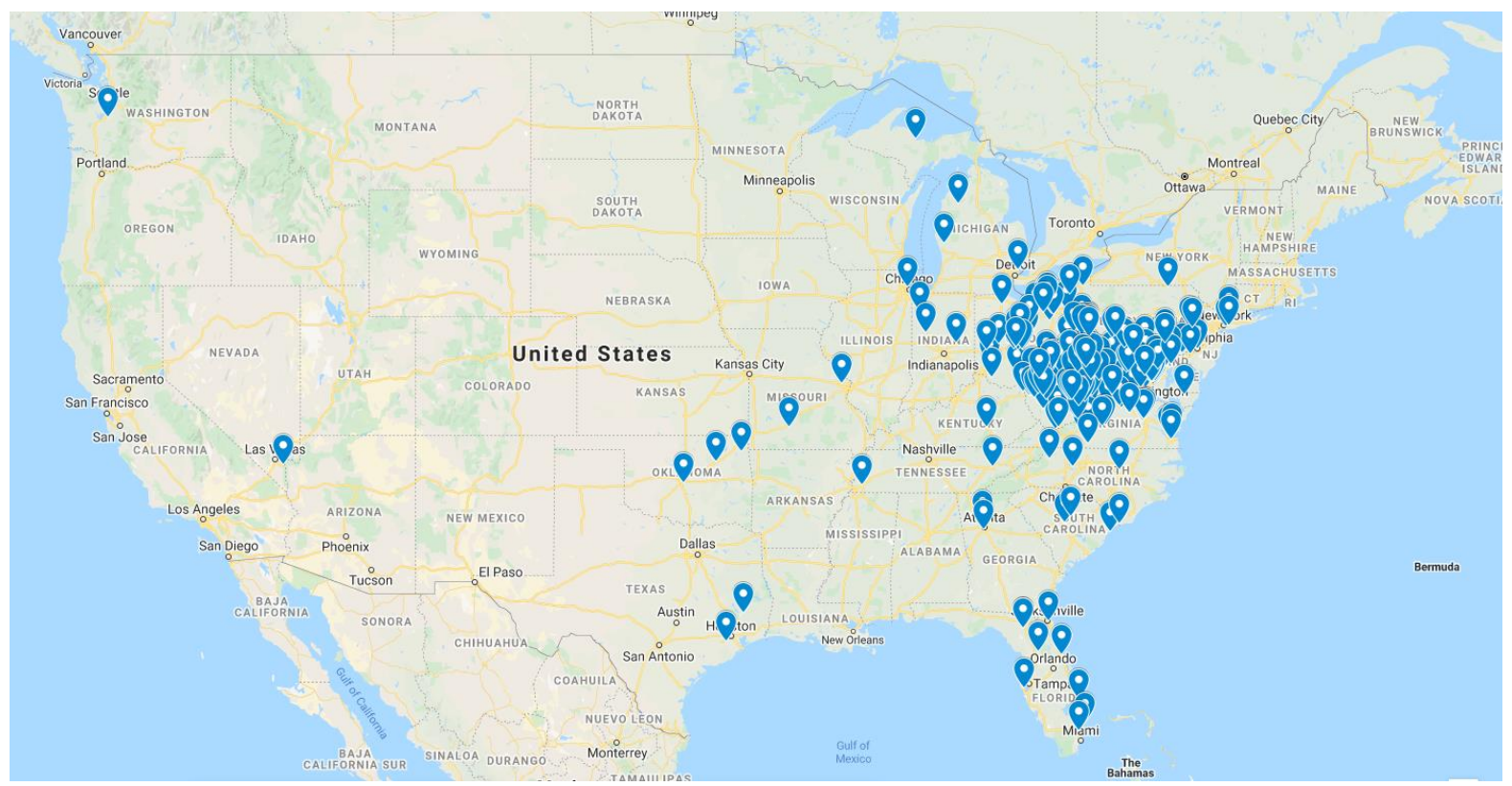

Figure 2: Distribution of home zip codes for FY 2009 Cluster 1 Visitors

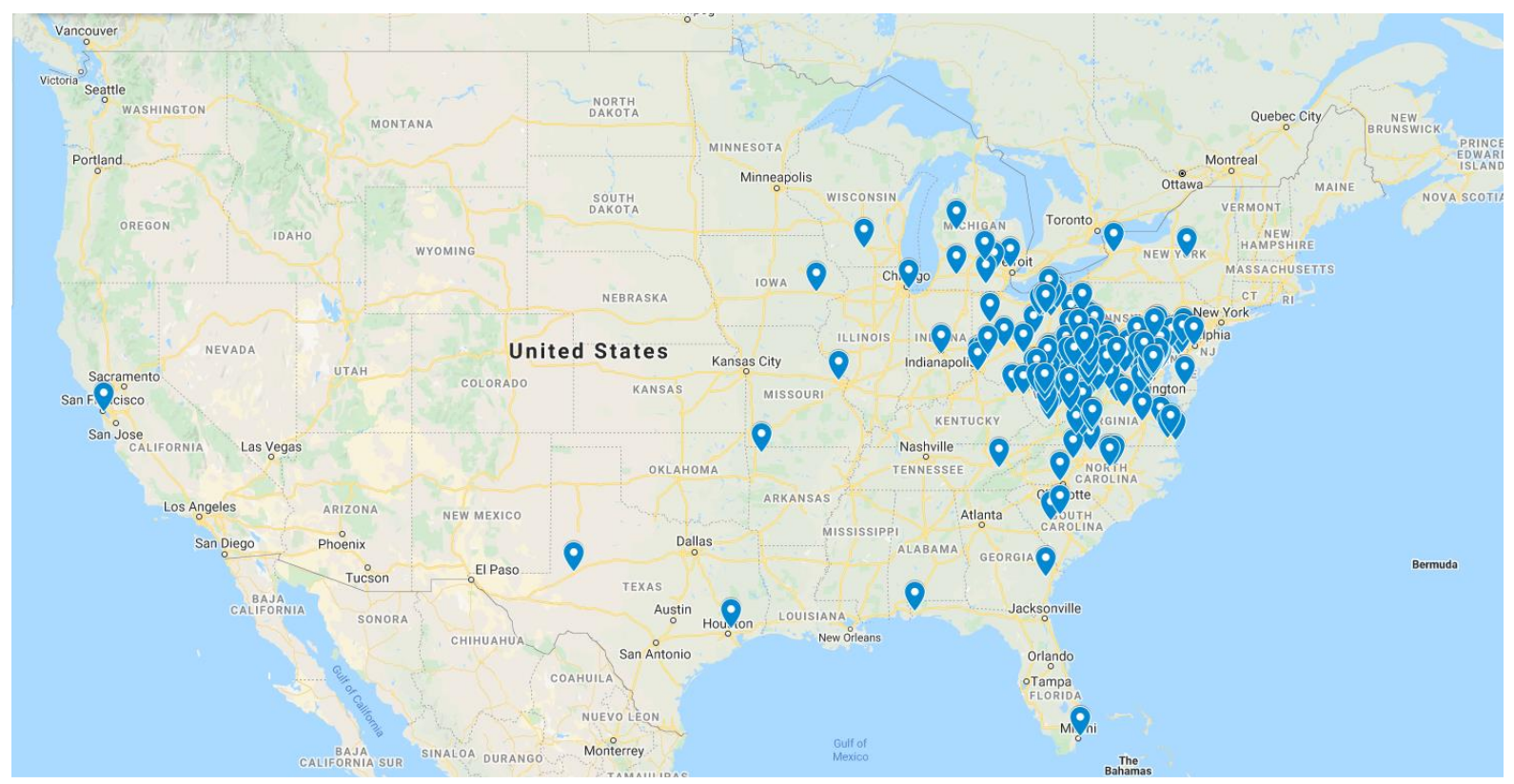

Figure 3: Distribution of home zip codes for FY 2014, Cluster 1 Visitors 


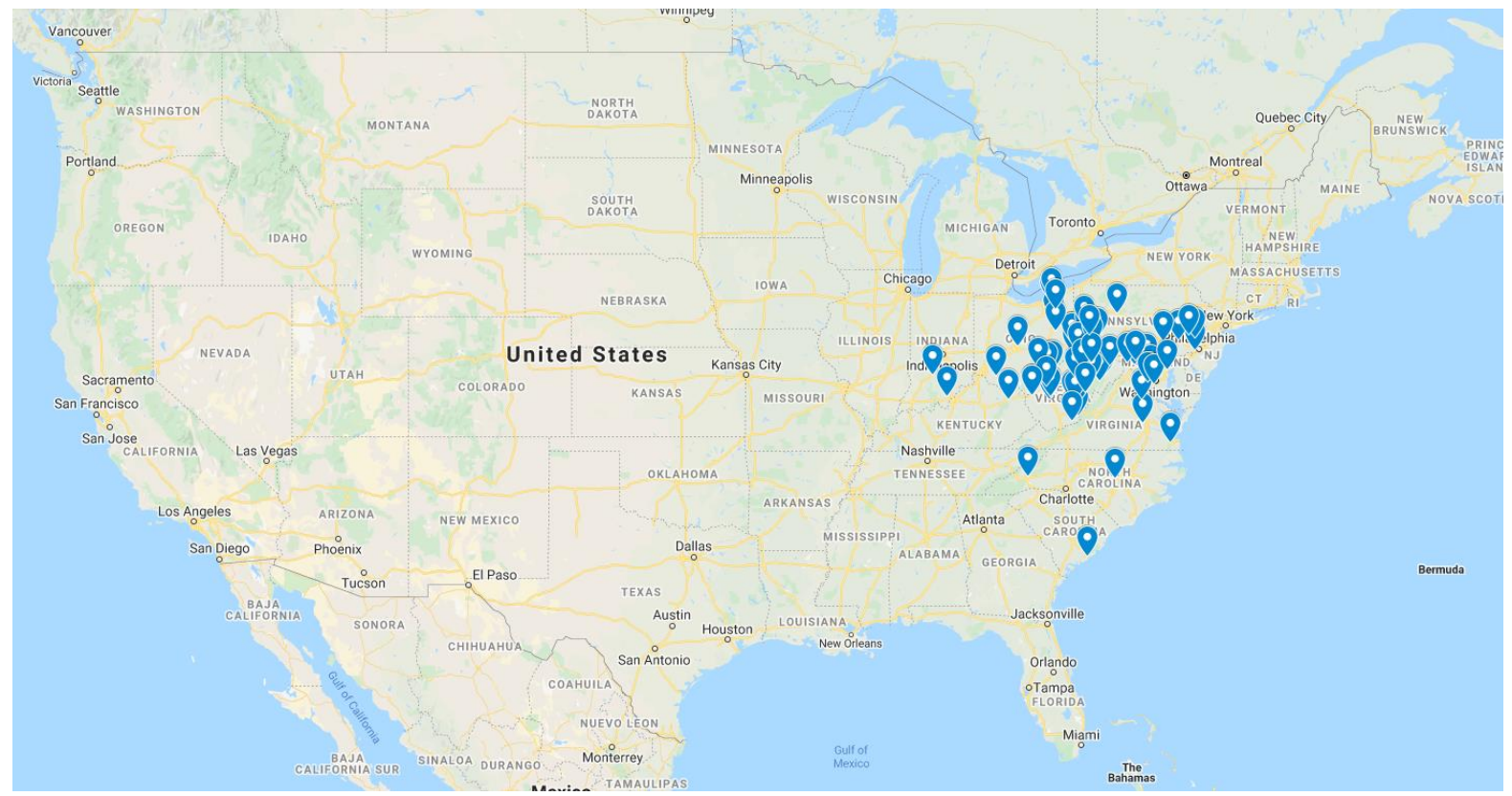

Figure 4: Distribution of home zip codes for FY 2009, Cluster 2 Visitors

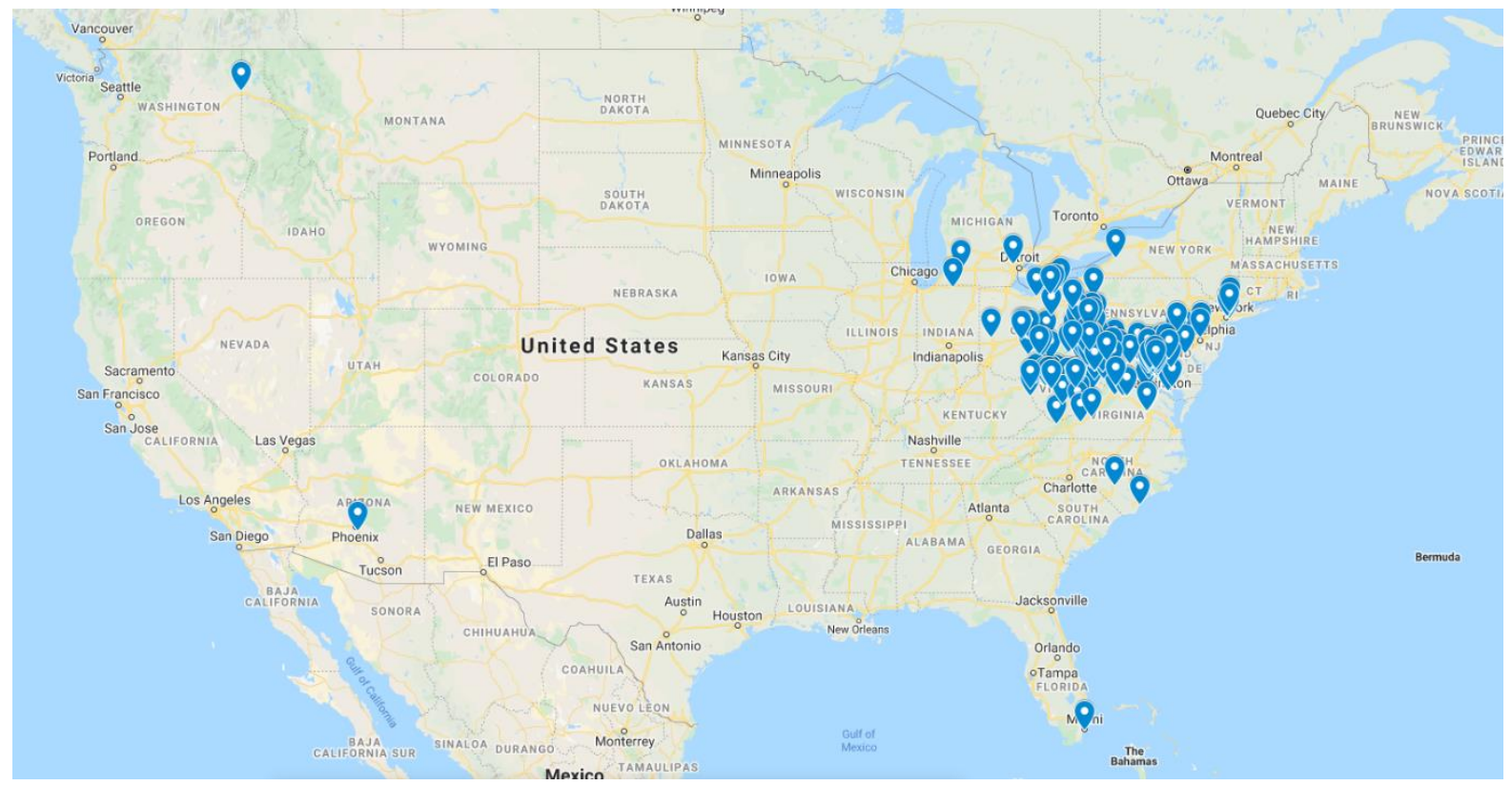

Figure 5: Distribution of home zip codes for FY 2014, Cluster 2 Visitors 


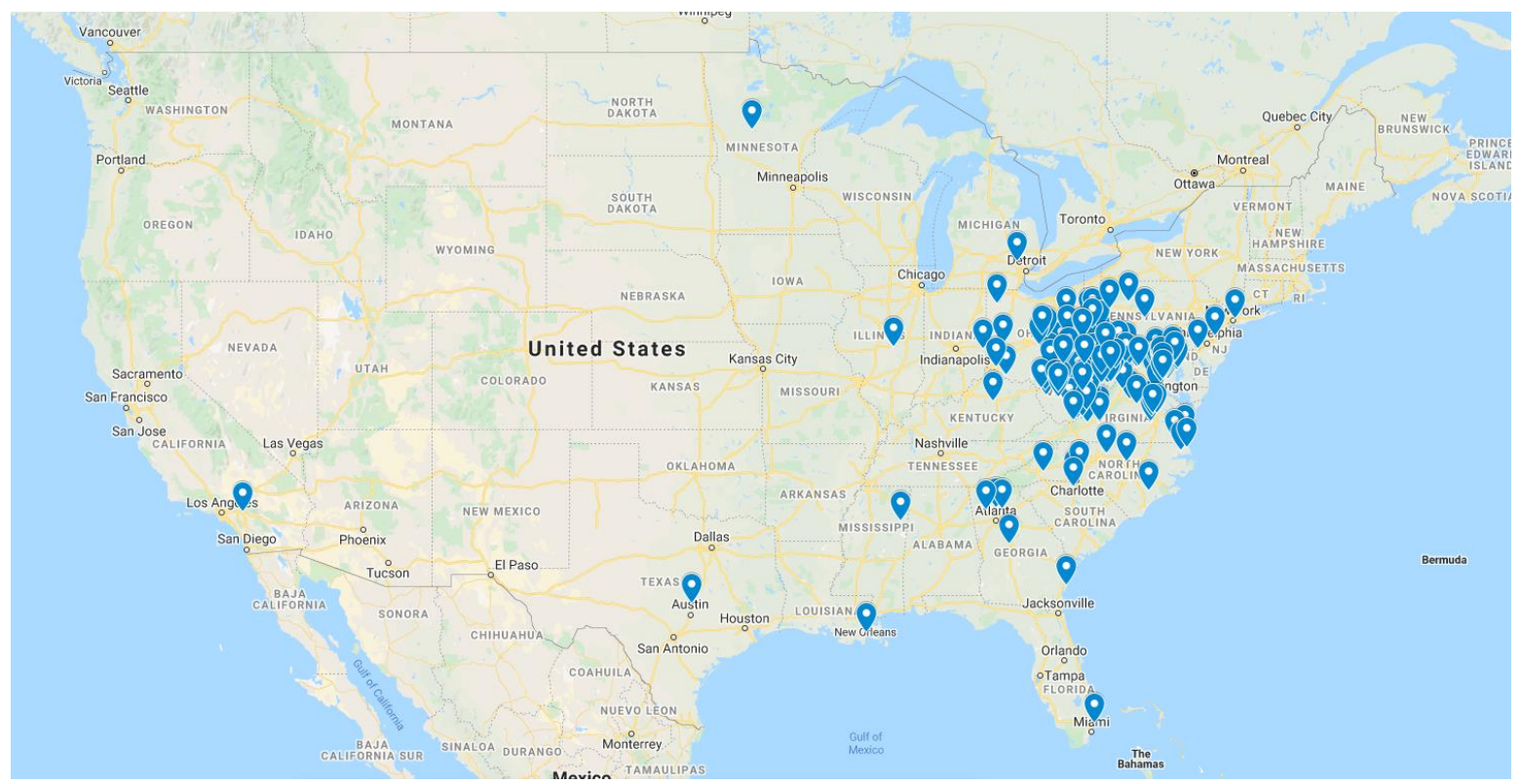

Figure 6: Distribution of home zip codes for FY 2009, Cluster 3 Visitors

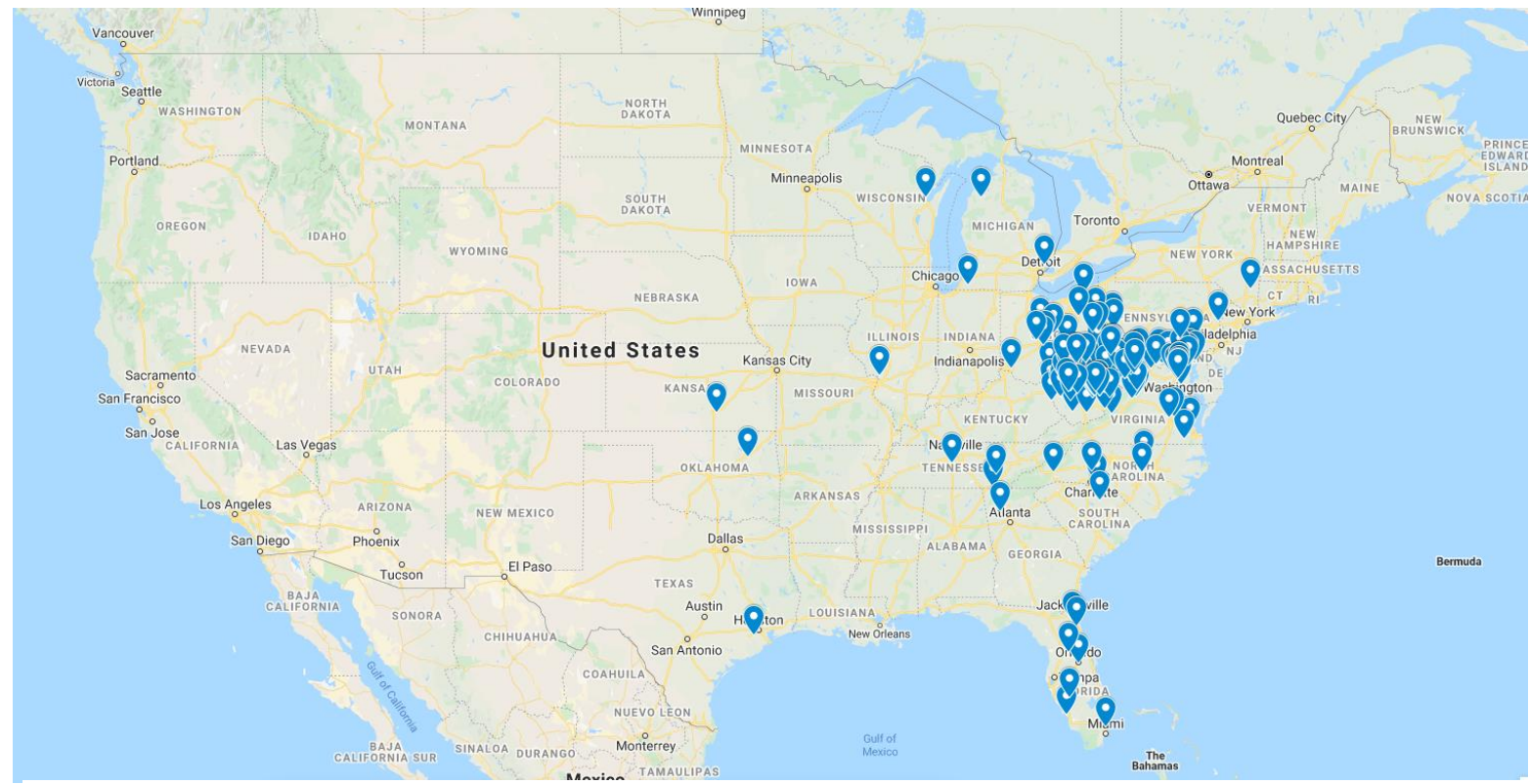

Figure 7: Distribution of home zip codes for FY 2014, Cluster 3 Visitors 


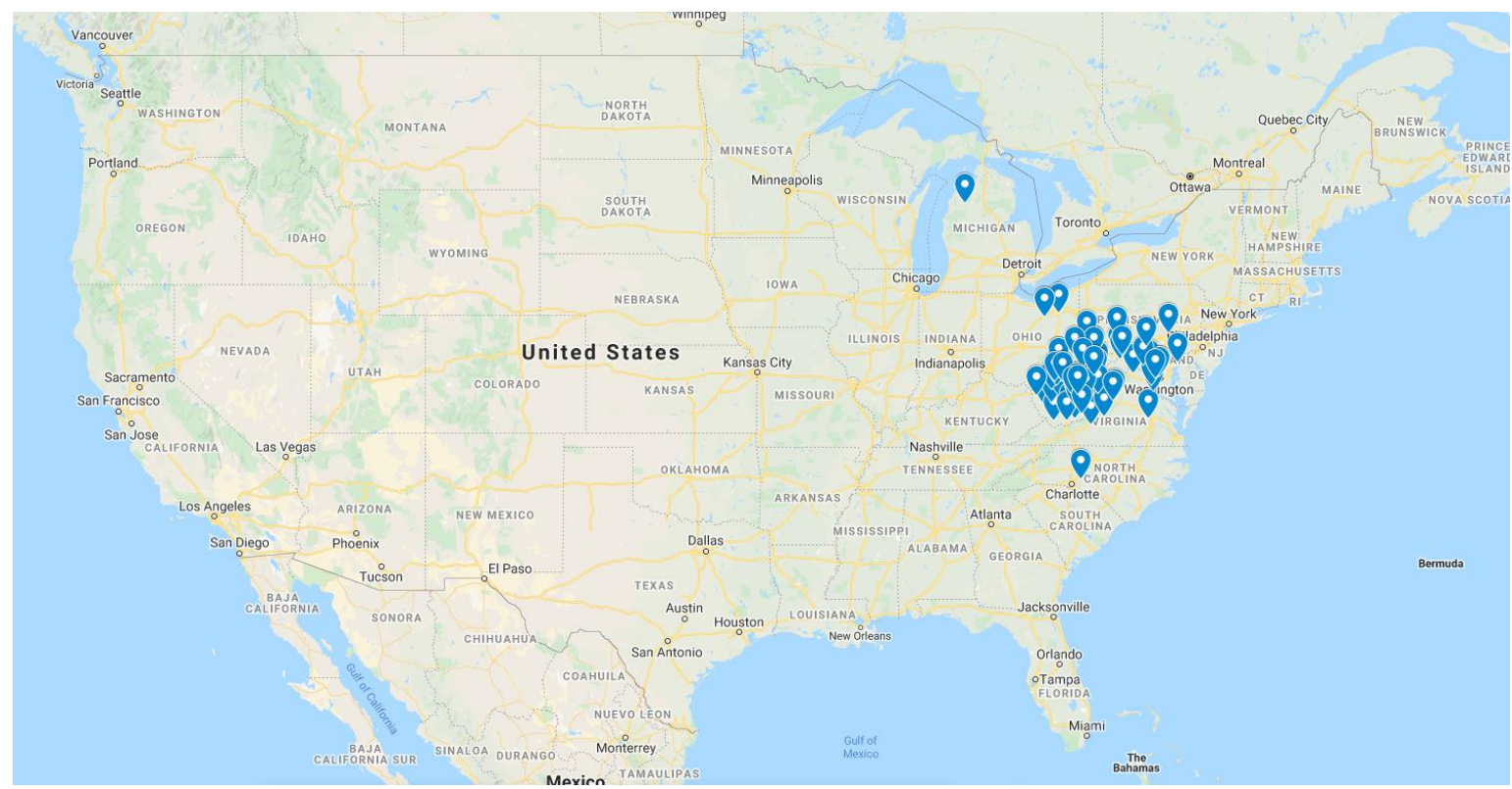

Figure 8: Distribution of home zip codes for FY 2009, Cluster 4 Visitors

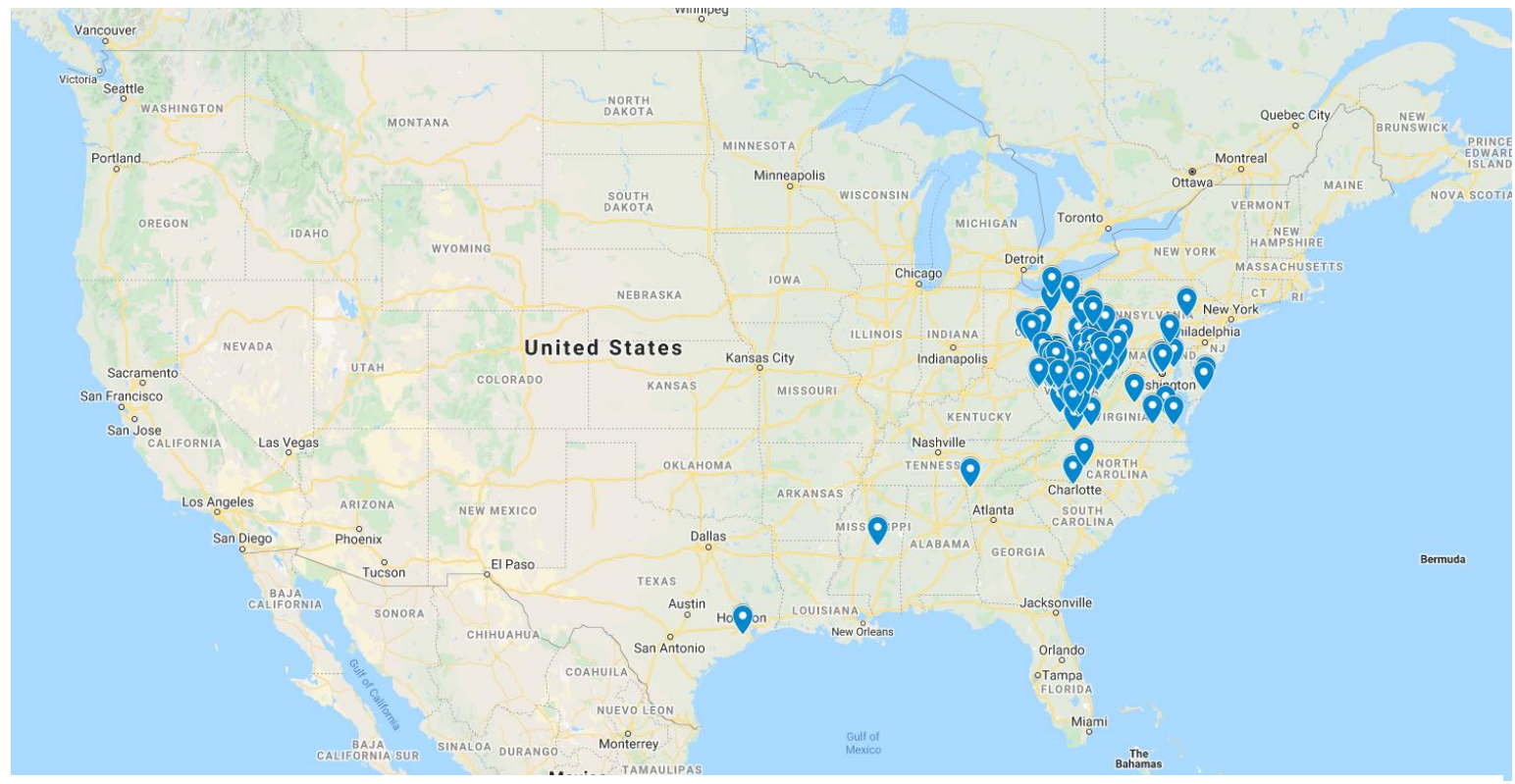

Figure 9: Distribution of home zip codes for FY 2014, Cluster 4 Visitors 


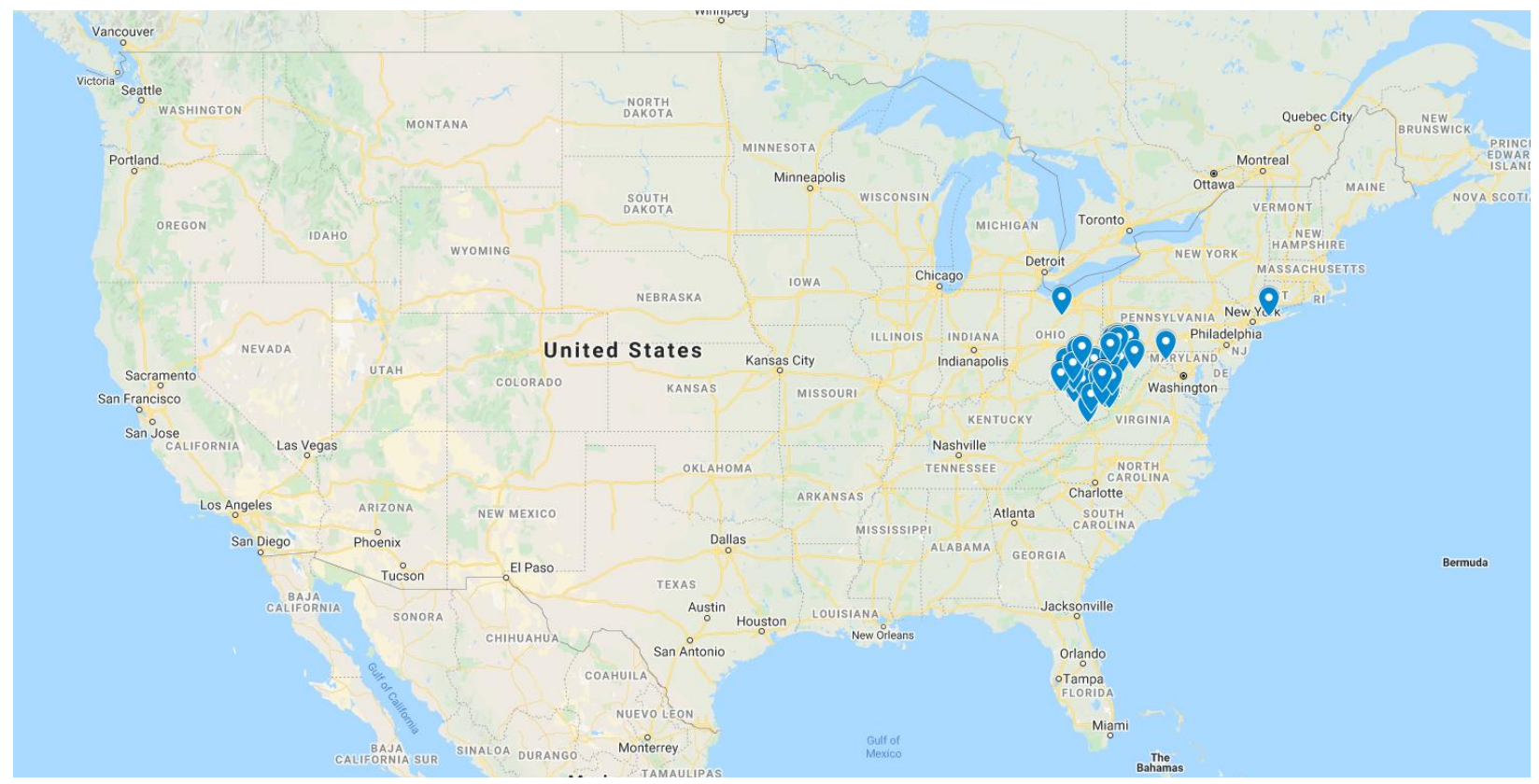

Figure 10: Distribution of home zip codes for FY 2009, Cluster 5 Visitors

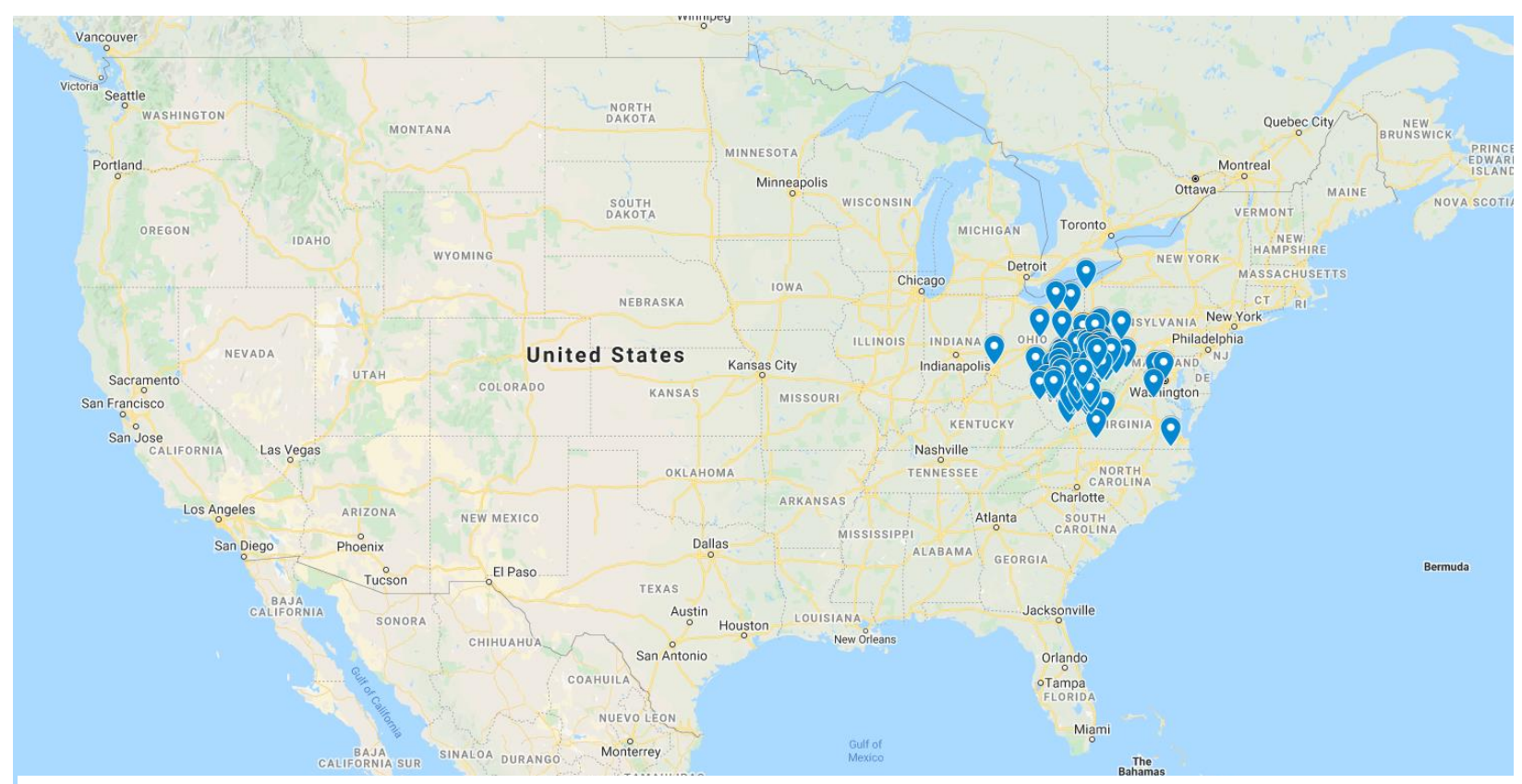

Figure 11: Distribution of home zip codes for FY 2014, Cluster 5 Visitors 


\section{Fiscal Year and Cluster Membership Differences in Travel Distance}

Two-way analysis of variance was used to examine differences in travel distance by fiscal year, cluster membership, and the interaction between the two variables (Table 7), and cluster membership $(p<.001)$ and interaction effects were significant $(p<.05)$. Tukey's post hoc comparisons $(\mathrm{p}<.05)$ were also examined. Visitors included in cluster 1 traveled farther than clusters 4 and 5 to get to the Monongahela National Forest, especially in fiscal year 2009 (Table 8). Cluster 2 and 3 visitors traveled farther than cluster 5 visitors.

\section{Table 7}

ANOVA summary table for travel distance.

\begin{tabular}{lllll}
\hline Source & $d f$ & $M S$ & $F$ & $p$ \\
\hline FY & 1 & 748553.17 & 2.59 & .108 \\
Cluster & 4 & 2486618.83 & 8.59 & $<.001$ \\
FY x Cluster & 4 & 735841.05 & 2.54 & .038 \\
\hline
\end{tabular}

Note: MS = Mean Squares

Table 8

Descriptive statistics for travel distance.

\begin{tabular}{lllll}
\hline FY & Cluster & Mean (Miles) & Std Deviation & N \\
\hline 2009 & 1 & 344.73 & 632.32 & 320 \\
& 2 & 426.24 & 1110.86 & 83 \\
& 3 & 256.21 & 545.38 & 182 \\
& 4 & 130.51 & 140.97 & 115 \\
& 5 & 92.97 & 79.44 & 69 \\
\hline 2014 & 1 & 292.71 & 577.24 & 256 \\
& 2 & 192.16 & 202.90 & 212 \\
& 3 & 242.33 & 757.42 & 198 \\
& 4 & 165.40 & 221.62 & 136 \\
& 5 & 127.97 & 130.41 & 171 \\
\hline
\end{tabular}

Note: Cluster 1: Relaxing in Nature Package; Cluster 2: Backpacking and Hiking Package; Cluster 3: Viewing Nature and Hunting Package; Cluster 4: Picnicking Package; Cluster 5:

Purely Fishing 


\section{Fiscal Year and Cluster Membership Differences in Trip Spending}

Two-way analysis of variance was used to examine the effect of fiscal year and cluster membership on total trip spending (Table 9). Economics questions can be found in Appendix E. Trip spending was significantly dependent on cluster membership $(p<.01)$ but not fiscal year. Specifically, Tukey's post hoc tests indicated that cluster 3 visitors spent more than clusters 2,4 , and 5 ( $\mathrm{p}<.05)$ during their trip regardless of fiscal year. In fiscal year 2009, cluster 3 had a mean spending of $\$ 724.46$ with a standard deviation of $\$ 1373.95$, cluster 2 had a mean spending of 313.80 with a standard deviation of $\$ 405.53$, cluster 4 had a mean spending of $\$ 193.52$ with a standard deviation of $\$ 162.77$, and cluster 5 had a mean spending of $\$ 171.83$ with a standard deviation of $\$ 248.58$. In fiscal year 2014 , cluster 3 had a mean spending of $\$ 386.63$ with a standard deviation of $\$ 737.64$, cluster 2 had a mean spending of $\$ 247.42$ with a standard deviation of $\$ 610.18$, cluster 4 had a mean spending of $\$ 229.38$ with a standard deviation of $\$ 202.52$, and cluster 5 had a mean spending of $\$ 274.33$ with a standard deviation of $\$ 274.33$

(Table 10).

\section{Table 9}

ANOVA summary table for trip spending.

\begin{tabular}{lllll}
\hline Source & $d f$ & $M S$ & $F$ & $p$ \\
\hline FY & 1 & 132300.35 & .28 & .595 \\
Cluster & 4 & 2010127.62 & 4.30 & .002 \\
FY x Cluster & 4 & 874794.33 & 1.87 & .114 \\
\hline
\end{tabular}

Note: MS = Mean squares 
Table 10

Descriptive statistics for trip spending.

\begin{tabular}{lllll}
\hline FY & Cluster & Mean & Std Deviation & N \\
\hline 2009 & 1 & 412.51 & 482.16 & 97 \\
& 2 & 313.80 & 405.53 & 25 \\
& 3 & 724.46 & 1373.95 & 54 \\
& 4 & 193.52 & 162.77 & 29 \\
& 5 & 171.83 & 248.58 & 18 \\
\hline 1 & 493.37 & 674.50 & 67 \\
& 2 & 247.42 & 610.18 & 69 \\
& 3 & 386.63 & 737.64 & 63 \\
& 4 & 229.38 & 202.52 & 32 \\
& 5 & 274.33 & 274.33 & 43 \\
\hline
\end{tabular}

Note: Cluster 1: Relaxing in Nature Package; Cluster 2: Backpacking and Hiking Package;

Cluster 3: Viewing Nature and Hunting Package; Cluster 4: Picnicking Package; Cluster 5:

Purely Fishing

\section{Fiscal Year and Cluster Membership Differences in Nights Away from Home during Trip}

Respondents were asked to report the number of nights they would be away from home during their trip. Nights away from home was significantly dependent on cluster membership $(\mathrm{p}<.01)$, and it approached significance $(\mathrm{p}=.07)$ with fiscal year (Table 11). Tukey's post hoc tests indicated that cluster 1 visitors spent more nights away from home than clusters 2 and 5 $(\mathrm{p}<.05)$ (Table 12). In fiscal year 2009 members of cluster 1 spent an average of 4.18 nights away from home, members of cluster 2 spent an average of 2.90 nights away from home, and members of cluster 5 spent an average of 1.93 nights away from home. In fiscal year 2014 members of cluster 1 spent an average of 3.34 nights away from home, members of cluster 2 spent an average of 2.04 nights away from home, and members of cluster 5 spent an average of 2.45 nights away from home. 


\section{Table 11}

ANOVA summary table for nights away from home.

\begin{tabular}{lllll}
\hline Source & $D f$ & $M S$ & $F$ & $p$ \\
\hline FY & 1 & 109.29 & 3.26 & .071 \\
Cluster & 4 & 132.40 & 3.95 & .003 \\
FY x Cluster & 4 & 43.12 & 1.29 & .273 \\
\hline
\end{tabular}

Note: MS = Mean squares

Table 12

Descriptive statistics for nights away from home.

\begin{tabular}{lllll}
\hline FY & Cluster & Mean & Std Deviation & N \\
\hline 2009 & 1 & 4.18 & 7.49 & 318 \\
& 2 & 2.90 & 3.41 & 83 \\
& 3 & 3.68 & 10.83 & 182 \\
& 4 & 2.88 & 3.71 & 115 \\
& 5 & 1.93 & 2.62 & 69 \\
\hline 2014 & 1 & 3.34 & 4.91 & 255 \\
& 2 & 2.04 & 2.30 & 212 \\
& 3 & 2.13 & 3.69 & 198 \\
& 4 & 2.83 & 4.78 & 136 \\
& 5 & 2.45 & 3.55 & 169 \\
\hline
\end{tabular}

Note: Cluster 1: Relaxing in Nature Package; Cluster 2: Backpacking and Hiking Package; Cluster 3: Viewing Nature and Hunting Package; Cluster 4: Picnicking Package; Cluster 5: Purely Fishing

\section{Fiscal Year and Cluster Membership Differences in Overall Satisfaction}

Respondents were also asked to rate their overall trip experience on a 5-point scale ranging from 1 (very dissatisfied) to 5 (very satisfied). Satisfaction questions can be found in Appendix F. Overall trip satisfaction was significantly dependent on fiscal year $(p<.001)$, cluster membership $(p<.001)$, and the interaction effect $(p<.05)$ (Table 13). Cluster 1's satisfaction level was significantly greater than clusters 3,4 , and $5(\mathrm{p}<.05)$ with a mean score in fiscal year 2009 of 4.78 and 4.87 in fiscal year 2014. Cluster 2 was significantly greater than 3 and 5 $(p<.05)$ with a mean score in fiscal year 2009 of 4.88 and 4.87 in fiscal year 2014 (Table 14). Means scores were also higher among clusters during fiscal year $2014(\mathrm{p}<.05)$. Satisfaction 
within cluster 1 grew by $.09, .11$ in cluster $3, .10$ in cluster 4 , and .38 in cluster 5 . Perhaps more trips to the Monongahela during the financial crisis were a second option for visitors because of lower costs, thus resulting in lower satisfaction scores because visitors couldn't afford their first option. Satisfaction was measured on a 5-point scale ranging from $1=$ very dissatisfied to $5=$ very satisfied.

\section{Table 13}

ANOVA summary table for overall satisfaction.

\begin{tabular}{lllll}
\hline Source & $d f$ & $M S$ & $F$ & $p$ \\
\hline FY & 1 & 6.07 & 15.64 & $<.001$ \\
Cluster & 4 & 7.86 & 20.27 & $<.001$ \\
FY x Cluster & 4 & 11.11 & 2.87 & .022 \\
\hline
\end{tabular}

Note: MS = Mean squares

\section{Table 14}

Descriptive statistics for overall satisfaction.

\begin{tabular}{lllll}
\hline FY & Cluster & Mean & Std Deviation & N \\
\hline 2009 & 1 & 4.78 & .58 & 320 \\
& 2 & 4.88 & .33 & 83 \\
& 3 & 4.60 & .79 & 182 \\
& 4 & 4.71 & .65 & 115 \\
& 5 & 4.23 & 1.13 & 69 \\
\hline 2014 & 1 & 4.87 & .42 & 256 \\
& 2 & 4.87 & .45 & 212 \\
& 3 & 4.71 & .64 & 197 \\
& 4 & 4.81 & .51 & 137 \\
& 5 & 4.61 & .80 & 171 \\
\hline
\end{tabular}

Note: Cluster 1: Relaxing in Nature Package; Cluster 2: Backpacking and Hiking Package; Cluster 3: Viewing Nature and Hunting Package; Cluster 4: Picnicking Package; Cluster 5: Purely Fishing. 


\section{Discussion}

The purpose of this study was to use activity-based segmentation to more closely examine the impact (both positive and negative) of the 2008-2009 financial crisis on the tourism market of the Monongahela National Forest. Five market segments were identified based on visitor participation in 18 outdoor recreation activities. The effect of the global economic downturn was not ubiquitous across market segments. Within the five market segments identified, some were winners and some were losers. When assessing winning and losing market segments during the financial crisis several factors were considered. Factors such as participation, satisfaction, travel distance, and nights away from home are all considered. This study shows that certain market segments had higher use levels than others during the 2008-2009 financial crisis than others. This study included seven research questions. Together, the answers to these research questions provide important information to the visitor trends on the Monongahela National Forest. A discussion of each of the five research questions follow below.

\section{$\underline{\text { Research Question \#1 }}$}

How has recreation participation changed over five years on the Monongahela National Forest following the world financial crisis in fiscal year 2009?

Over the course of five years, recreation participation has changed in some way in most of the market segments listed in this study while only a few segments showed little change. Beginning with cluster 1 (Relaxing in Nature), recreation participation was found to be higher in 2009 than in 2014 suggesting that the activities associated with the Relaxing in Nature Package were more preferred during bad economic times. Cluster 2 (Backpacking and Hiking) had significantly higher participation in fiscal year 2014 than in fiscal year 2009. These results show that 
recreation activities associated with cluster 2 were more favorable during good economic times. Recreation participation did not change much in clusters 3 and 4 (Viewing Nature and Hunting, Picnicking). This means that visitor participation in outdoor recreation activities associated with both clusters showed little to no effect from good or bad economic times. Cluster 5 (Purely Fishing) was another cluster that showed significant change over the five-year period. The participation in the recreational activity of fishing was much higher in fiscal year 2014 than it was in fiscal year 2009 suggesting that it is a more favorable activity during good economic times.

\section{$\underline{\text { Research Question \#2 }}$}

What are the activity-based market segments?

Two-step cluster analysis of 18 activity participation variables (binary "yes" or "no" data) were conducted with 3 to 5 clusters examined to find the most logical solution for the entire data set. Based on criteria provided by Weinstein (1987), a five-cluster solution was selected showing that five activity-based market segments were found to best describe the visitor activity on the Monongahela National Forest in fiscal years 2009 and 2014. These five clusters are: 1) Relaxing in Nature Package, 2) Backpacking and Hiking Package, 3) Viewing Nature and Hunting Package, 4) Picnicking Package, and 5) Purely Fishing.

\section{$\underline{\text { Research Question \#3 }}$}

For each market segment, was there a difference in visitor demographics between fiscal years 2009 and $2014 ?$ 
Visitor demographics were compared within each market segment to determine if there were differences within each segment depending on the fiscal year. The specific demographics compared by fiscal year for each market segment were gender, age, and household income. The only significant change in demographics involved the Purely Fishing market segment. In the Purely Fishing Segment, there were fewer cluster members for age groups 50-59, 60-69, and 70+ during the financial crisis. That is, older anglers may have been unable to participate during fiscal year 2009 due to financial constraints. In fiscal year 2014 participation in Purely Fishing by visitors aged $70+$ grew from $1.4 \%$ to $11.1 \%$ potentially due to the better economy.

\section{$\underline{\text { Research Question \#4 }}$}

What are the main and interaction effects of fiscal year and cluster membership on travel distance, trip expenditures, nights away from home, and overall satisfaction?

Based on the two-way analysis of variance that was used to examine differences in travel distance by fiscal year, cluster membership, and the interaction between the two variables, the interaction effects were found to be significant. It was found that visitors of cluster 1 traveled further than visitors of clusters 4 and 5 to participate in recreation on the Monongahela National Forest. This was found to be especially true for fiscal year 2009. Clusters 2 and 3 visitors also traveled further than visitors in cluster 5.

Trip spending was found to be significantly dependent on cluster membership. Cluster 3 visitors spent more than visitors included in clusters 2,4 , and 5 regardless of fiscal year. These results indicate that good or bad economic times do not play a significant role in the amount of spending of visitors within each market segment. 
The amount of nights visitors spent away from home was significantly dependent upon cluster membership and was approaching significance with fiscal year. This indicates that the amount of nights visitors spent away from home was dependent upon their market segment with the possibility of it being effected by the economy.

Overall visitor satisfaction was significantly dependent upon fiscal year, cluster membership, and the interaction effect. This shows that several factors play a role in the overall satisfaction of visitors. Visitor satisfaction may be effected by the economy, the market segment, and a combination of the two.

\section{$\underline{\text { Research Question \#5 }}$}

Was the "global economic downturn" ubiquitous across all market segments?

This study shows that the effect of the global economic downturn was not ubiquitous across market segments. Within the five market segments identified, some were winners and some were losers. The following will provide insight on which market segments were found to be winners and which market segments were found to be losers.

\section{Market Winner}

There are several actions that tourism providers on the Monongahela National Forest can take during mega events like an economic downturn. The greatest growth potential involves promoting and attracting visitors that participate in cluster 1 activities: Relaxing in Nature Package. (The package was 13.9 percent larger in cluster membership during fiscal year 2009). This market segment made up the largest percent of the tourist population in this study, traveled farther, spent more nights away from home, and were more satisfied when compared to some other segments that were examined. What makes this cluster unique are activities such as viewing nature, hiking, relaxing, viewing wildlife, driving for pleasure, nature centers, history, 
nature study and staying in resorts, cabins, or other accommodations. Many visitors do not have the time to participate in a combination of preferred activities on their own (Hsieh, O'Leary, \& Morrison, 1992). Tourism providers can make it more convenient for visitors by offering activity packages for this target market, especially during an economic downturn. There is a lot of room for creativity when developing travel packages because this activity set has the largest number of activities among the clusters that were examined. Nature centers can serve as a hub for these activity packages given more than half of cluster 1 members visit them during their stay. Providing overnight accommodation such as resorts and cabins as part of the package may also be a valid option, especially considering the lengthier trips that are taken.

It is not surprising that Relaxing in Nature Package was more popular during the financial crisis. As mentioned earlier, the recession was an extremely stressful time for most employees (Hochwarter, 2009). Perhaps more visitors were seeking the stress reducing benefits of nature (e.g., relaxing and viewing nature) during their visit to the forest. Although the authors are not aware of any studies that have documented this increase in nature-seeking activities during a crisis, this finding does complement the plethora of literature on the mental health benefits of nature and provides face validity for these results. National Forests may play a critical role in easing stress during a crisis through relaxing in nature. It is also important to note the low cost of most activities within the Relaxing in Nature package. Activities such as viewing nature, hiking, relaxing, and viewing wildlife are typically free of charge. While the economic downturn was mentally stressful for most people, it was also a very stressful time financially. It is possible that visitors chose activities related to the Relaxing in Nature package due to the low cost of most activities because they were struggling financially during the financial crisis. As mentioned 
before, tourism providers would benefit from the development of activity packages and advertise the low cost of specific activities to their target market.

Market Losers Cluster 2 visitors (Backpacking and Hiking Package) may have been displaced during the financial crisis, but they were more satisfied than clusters 3 and 5. This segment includes a package of activities including hiking, viewing wildlife, and backpacking. The average visitor in this market traveled much farther during fiscal year 2009, especially when compared to cluster 5 . Visitors in cluster 2 also spent less money than most clusters, especially clusters 1 and 3. Cluster 2 visitors spent less nights away from home. During the financial crisis, visitors in this cluster were traveling longer distances to possibly participate in shorter weekend getaways instead of longer more expensive vacations. Regional marketing may work better for this segment during a financial crisis that focuses on short inexpensive trips to the Forest.

Cluster 5 visitors (Purely Fishing) also were less likely to visit the forest during the financial crisis. Nearly all visitors of this cluster participated in fishing. Older anglers were displaced during fiscal year 2009 perhaps due to financial constraints. The visitors in this cluster were less satisfied, especially during the financial crisis and they spent less money. Visitors also drove shorter distances during the crisis. Because visitors are more likely to travel to the forest to participate in fishing during a strong economy, regional marketing may be a more effective tactic during strong economic times.

\section{$\underline{\text { Research Question \#6 }}$}

Are the 5 activity packages proposed by Hendee, Gale, and Cotton (1971) represented on the Monongahela National Forest? 


\section{Activity Package Typology}

The five clusters identified in this study represent four of the five classes of activity packages proposed by Hendee, Gale, and Catton (1971) and builds support for their framework. Cluster 1 visitors participated in viewing nature and hiking which would fall under the AppreciativeSymbolic class. Cluster 1 also demonstrates Passive-Free Play through activities such as relaxing and driving for pleasure and Sociable-Learning through nature study. Cluster 2 is purely Appreciative-Symbolic and includes hiking, backpacking, and viewing wildlife. Clusters 3 and 5 are more Extractive-Symbolic and include fishing and hunting activities. Cluster 4, which includes picnicking, most closely fits within the Passive Free-Play class. The only class that is not represented in this study is Active-Expressive because no clusters meet the definition of this class.

\section{$\underline{\text { Research Question \#7 }}$}

How much activity variety exists within each activity package on the Monongahela National Forest?

\section{Variety within an Activity Package}

Sievänen, Neuronen, and Pouta (2018) examined if involvement in one outdoor activity reduced participation in other activities, and their starting point was the study of fishers. Their results suggest that people who are active in one outdoor recreation activity can also be active in others. In fact, this seems to be true even during a single recreation outing. This study's results suggest that most recreation on the forest took place as a package, with the exception of anglers. This finding deserves additional research. 
Questions about variety within an activity package emerged from this study. The concept of variety is somewhat different than the concept of behavioral involvement which was defined by Kim, Scott, and Compton (1997) as "the time and intensity of effort expended in a particular activity" (Sievänen, Neuronen, \& Pouta, 2018, p. 1). Sievänen, Neuronen, \& Pouta (2018) define activity variety as the number of activities represented in an activity package, especially the number of activities from different package classes. Cluster 1 clearly has the most variety of activities. In fact, it is the only cluster that falls under three different activity package classes. Cluster 3 and 5 tend to be more Extractive-Symbolic and have the least activity variety within the package. It is interesting to note that clusters 3 and 5 also had the lowest overall satisfaction scores during both fiscal years 2009 and 2014. It is possible that "activities in the same cluster provide similar satisfactions. Thus, for many people, some of those activities may be substitutable with little loss of satisfaction (Hendee \& Burdge, 1974, p. 106). Clusters 3 and 5 may offer little substitutability making it difficult to deal with the potential effects of crowding and displacement (Manning, 2011). Future research is needed to better understand the possible challenges when participating in those pure activity packages.

\section{Conclusion}

Five activity clusters describe the range of market segments on the Monongahela National Forest. That is, all 18 activities were significantly associated with cluster membership $(\mathrm{p}<.001)$ and generally represent the activity package typology. The most significant finding of this study was identifying the Relaxing in Nature Package (cluster 1) which was more popular during the financial crisis. Little, if any, research had documented positive impacts of the global economic downturn on tourism at the local level. However, by examining specific market segments at a 
smaller scale, the authors were able to identify opportunities for tourism providers during challenging times. Relaxing in Nature Package may provide the greatest opportunity for growth given this is the most popular activity package and it includes visitors that tend to spend more nights than some other clusters of visitors. The Backpacking and Hiking Package (cluster 2) and the Fishing Package (cluster 5) were both identified as market segments with low opportunity during bad economic times but some potential during good economic times. Cluster 2 shows potential during good economic times because of their growth in participation during fiscal year 2014 as well as their higher satisfaction in 2014. Cluster 5 shows potential during good economic times based on their higher participation in fiscal year 2014.

Many visitors also traveled farther to get to the forest and stayed longer during fiscal year 2009 making regional marketing more important during a financial crisis. This is somewhat different than what happened in parts of Europe (e.g., Germany) where tourists traveled closer, shorter, and cheaper (Reinhardt, 2011). This also contradicts Rittichainuwat et al. (2014) conclusions that tourist seek short-distance destinations during a financial crisis (at least in terms of driving distance). Although many visitors to the Monongahela National Forest traveled farther and stayed longer, their trips may have been cheaper than other options such as air transportation. It is possible that the visitors to the Monongahela National Forest chose a trip to the forest as their vacation over a more expensive trip to save money during the financial crisis. This decision would explain the longer stays and further travel distance than what was seen in other studies such as Reinhardt (2011) and Rittichainuwat et al. (2014).

At the time of this study, we are experiencing a historic event: COVID-19. Even though a pandemic and a financial crisis are different in many ways, there are similarities. Many people have either lost their jobs or were out of work for a period of time. This has effected a large 
majority of people financially. This study has the potential to be used by tourism providers to better target specific market segments. In 2009 during the financial crisis, specific segments saw higher participation than others. Future research is needed to fully understand the similarities and differences between the two events, but the results found in this study provide potential insight for tourism providers on possible visitor behavior that may occur due to the current pandemic.

\section{Future Research}

Future research that utilizes NVUM data or data collected from forests or parks to segment visitors based on their activity participation could benefit from knowing if five clusters were adequate when describing the range of markets in this study. This is generally consistent with the recent literature on activity-based market segmentation where four segments were the average. Comparing this study's findings with future research as it relates to forest recreation and tourism is needed and will fill a gap in the literature.

No studies have been published that used fiscal year 2009 NVUM data to examine the impact of the financial crisis on visitation. Future research should take advantage of this data to see if the same market winners and losers are identified across the country. This research could also be compared with US Forest Service data that is scheduled to be collected around the time of the Coronavirus epidemic. COVID-19 is likely to be different than the 2008-2009 financial crisis because it also includes a medical crisis wherein demand is influenced by laws that are based on the emergency state and not just economic reasons. Researchers across the country are currently exploring the effects of COVID-19 on outdoor recreation. The Leave No Trace Center for Outdoor Ethics and Pennsylvania State University surveyed over 1000 outdoor recreationalists to assess the change in recreation. The findings from this study show that recreationalists are going 
out alone more often, they are staying closer to home, they are changing activities, and guidelines are directing recreation behaviors (Center for Outdoor Ethics, 2020). These similarities and differences should be explored, and activity-based segmentation may prove useful when making those comparisons. Tourism and crises are a never-ending story. This study will hopefully help both public and private industry tourism providers on the Monongahela National Forest deal with current and future financial crises. 


\section{References}

Askew, A. E., Bowker, J. M., English, D. B. K., Zarnoch, S. J., \& Green, G. T. (2017). A

temporal importance-performance analysis of recreation attributes on National Forests. General Technical Report SRS-223.

Barić, D., Anić, P., \& Bedoya, A. M. (2016). Segmenting protected area visitors by activities: A case study in Paklenica National Park, Croatia. European Journal of Tourism Research, $13,103-121$.

Beritelli, P., \& Boksberger, P. (2005). Activity-based market segmentation: A behavioural approach. Tourism, 53(3), 259-266.

Boekstein, M. S., \& Spencer, J. P. (2013). Activity-based market segmentation of visitors to thermal spring resorts in the Western Cape Province, South Africa: Assessing the potential for health tourism development. African Journal for Physical, Health Education, Recreation and Dance, 19(4:2), 1100-1110.

Center for Outdoor Ethics. (2020) Leave no trace COVID-19 research. Retrieved from https://lnt.org/research-resources/leave-no-trace-covid-19-research/

Choi, H. S. C., Murraya, I., \& Kwana, K. (2011). Activity based segmentation of Canadian domestic pleasure travelers to New Brunswick. International Journal of Hospitality and Tourism Administration, 12(3), 202-224. https://doi.org/10.1080/15256480.2011.590736

Choi, W. M., \& Tsang, C. K. L. (2000). Activity based segmentation on pleasure travel market of Hong Kong private housing residents. Journal of Travel \& Tourism Marketing, 8(2), 75-97. https://doi.org/10.1300/J073v08n02_06

Coles, T. (2013). Much ado about nothing? Tourism and the financial crisis. In G. Visser and S. Ferreira (Eds.), Tourism in crisis (pp. 35-52). New York, NY: Routledge. 
Cooper, C., Fletcher, J., Fyall, A., Gilbert, D., \& Wanhill, S. (2005). Tourism principles and practice (3rd ed). Harlow: Pearson Education.

Eusébio, C., Carneiro, M. J., Kastenholz, E., Figueiredo, E., \& da Silva, D. S. (2017). Who is consuming the country side? An activity-based segmentation analysis of the domestic rural tourism market in Portugal. Journal of Hospitality and Tourism Management, 31, 197-210. https://doi.org/10.1016/j.jhtm.2016.12.006

Hendee, J., and Burdge, R. (1974). The substitutability concept: Implications for recreation management and research. Journal of Leisure Research, 6, 157-162. https://doi.org/10.1080/00222216.1974.11970178

Hendee, J. C., Gale, R. P., \& Catton, W. R., Jr. (1971). A typology of outdoor recreation activity preferences. The Journal of Environmental Education, 3(1), 28-34. https://doi.org/10.1080/00958964.1971.10801604

Hochwarter, W. (2009, March 12). Families are feeling stress of economic crisis. Science Daily. Retrieved from www.sciencedaily.com/releases/2009/03/090312115049.htm

Hsieh, S., O'Leary, J. T., \& Morrison, A. M. (1992). Segmenting the international travel market by activity. Tourism Management, 13(2), 209-223. https://doi.org/10.1016/0261-5177(92)90062-C

Lang, C. T., \& O'Leary, J. T. (1997). Motivation, participation, and preference: A multisegmentation approach of the Australian nature travel market. Journal of Travel and Tourism Marketing, 6(3/4), 159-180. https://doi.org/10.1300/J073v06n03_10

Manning, R. E. (2011). Studies in outdoor recreation: Search and research for satisfaction $\left(3^{\text {rd }}\right)$. Corvallis, OR: Oregon State University. 
McCool, S. F. (1978). Recreation activity packages at water-based resources. Leisure Sciences, l(2), 163-173. https://doi.org/10.1080/01490407809512879

McKercher, B., Ho, P. S. Y., du Cros, H., \& So-Ming, B. C. (2002). Activities-based segmentation of cultural tourism market. Journal of Travel and Tourism Marketing, 12(1), 23-45. https://doi.org/10.1300/J073v12n01_02

Meng, X., Siriwardana, M., Dollery, B., \& Mounter, S. (2010). The impact of the 2008 world financial crisis on tourism and the Singapore economy and policy responses: A CGE analysis. International Journal of Trade, Economics and Finance, 1(1), 46-53.

Mihalič, T., Kester, J., \& Dwyer, L. (2013). Impacts of the global financial crisis on African tourism: A tourism confidence index analysis. In G. Visser \& S. Ferreira (Eds.), Tourism in crisis (pp. 94-112). New York, NY: Routledge.

Moscardo, G., Pearce, P., Morrison, A., Green, D., \& O'Leary, J. T. (2000). Developing a typology for understanding visiting friends and relatives markets. Journal of Travel Research, 38(3), 251-259. https://doi.org/10.1177/004728750003800307

Mucci, N., Giorgi, G., Roncaioli, M., Perez, J. F., \& Arcangeli, G. (2016). The correlation between stress and economic crisis: a systematic review. Neuropsychiatric Disease and Treatment, 12, 983-993.

Mumuni, A. G., \& Mansour, M. (2014). Activity-based segmentation of the outbound leisure tourism market of Saudi Arabia, Journal of Vacation Marketing, 1-14. https://doi.org/10.1177/1356766714522258

Ordell, K. (2012). Outdoor recreation trends and futures. 
Pesonen, J. A., \& Tuohino, A. (2017). Activity-based market segmentation of rural well-being tourists: Comparing online information search. Journal of Vacation Marketing, 23(2), 145-158. https://doi.org/10.1177/1356766715610163

Reinhardt, U. (2011). Closer, shorter, cheaper: how sustainable is this trend? In R. Conrady \& M. Buck (Eds.), Trends and issues in global tourism 2011 (pp. 27-36). Berlin/Heidelberg: Springer.

Riley, C. J., Pierskalla, C. D., Burns, R. C., Maubme, K. C., Graefe, A. R., Smaldone, D. A., \& Williams, S. (2015). Examining OHV user displacement at the Oregon Dunes National Recreation Area and Sand Lake: A 10-year trend study. Journal of Outdoor Recreation and Tourism, 9, 44-52. https://doi.org/10.1016/j.jort.2015.04.002

Ritchie, J. R. B., Molinar, C. M. A., \& Frechtling, D. C. (2010). Impacts of the world recession and economic crisis on tourism: North America. Journal of Travel Research, 49, 5-15. https://doi.org/10.1177/0047287509353193

Rittchainuwat, B. N., Chakraborty, G., \& Rattanaphinanchai, S. (2014). Tourists' motivations to travel during financial crisis. Journal of Quality Assurance in Hospitality \& Tourism, 15(1), 100-113. https://doi.org/10.1080/1528008X.2014.855541

Schneider, P. P., Vogt, C., \& Smith, S. W. (2006). Segmenting the adventure travel market by activities: An extension of Sung, Morrison, and O'Leary. 37. Dublin: TTRA (Travel and Tourism Research Association).

Schroeder, T. D. (1987). Market segmentation for recreation, parks and tourism administration. Public Administration Series (pp. 1-4), US: Northern Arizona University. 
Sievänen, J., Neuronen, M., \& Pouta, E. (2018). Does involvement in one outdoor activity reduce participation in other activities: Are enthusiastic fishers only fishers? Journal of Outdoor Recreation and Tourism, 21, 1-9. https://doi.org/10.1016/j.jort.2017.11.003

Song, H., \& Lin, S. (2010). Impacts of the financial and economic crisis on tourism in Asia. Journal of Travel Research, 49(1), 16-30. https://doi.org/10.1177/0047287509353190

Sung, H. Y., Morrison, A. M., \& O'Leary, J. T. (1997). Segmenting the adventure travel market: From the North American industry providers' perspective. Journal of Travel and Tourism Marketing, 9(4), 1-20. https://doi.org/10.1300/J073v09n04_01

Tkaczynski, A., Rundle-Thiele, S. R., \& Prebensen, N. K. (2015). Segmenting potential naturebased tourists based on temporal factors: The case of Norway. Journal of Travel Research, 54(2), 251-265. https://doi.org/10.1177/0047287513514296

Visser, G. \& Ferreira, S. (Eds.). (2013). Tourism and Crisis. New York, NY: Routledge.

Weinstein, A. (1987). Market segmentation: Using demographics, psychographics and other segmentations techniques to uncover and exploit new markets. Chicago: Probes. https://doi.org/10.1002/dir.4000010410

Wight, P. A. (1996). North American ecotourists: Market profile and trip characteristics. Journal of Travel Research, 34(2), 2-10. https://doi.org/10.1177/004728759603400401

Williams, D. R. (1988). Measuring perceived similarity among outdoor recreation activities: A comparison of visual and verbal stimulus presentations. Leisure Sciences, 10(3), 153166. https://doi.org/10.1080/01490408809512186

World Travel and Tourism Council (WTTC). (2010). Progress and priorities, 2009-2010. London: WTTC. 


\section{Appendices}

Appendix A - Section 1: Screening Questions.............................................64

Appendix B - Section 2: National Forest Visit Questions..............................65

Appendix C - Section 3: This Trip Away From Home..................................66

Appendix D - Section 4: Demographics...................................................67

Appendix E - Economics Questions........................................................68

Appendix F - Satisfaction Questions....................................................69 


\section{Section 1: Screening Questions}

Q1: Would you be willing to take a few minutes to participate in this interview?

Q2. What is your home zip code?

Q3. What is the primary purpose of your visit to (say site name)?

Q4. When do you plan to leave (say site name) for the last time on this visit?

Q5. When did you first arrive at (say site name) on this visit?

Q3a: What is the primary purpose of your visit to this (say NF name) National Forest?

Q3b. What is the major reason you chose this route?

Q4. Today we are interested in interviewing people who have recreated in the undeveloped areas of this National Forest. This includes things like hiking trails (not in designated Wilderness), exploring forest roads, fishing and camping in undeveloped areas. Have you recreated in the undeveloped areas of this Forest sometime during your visit?

Q5. Are you leaving the undeveloped portion of this National Forest for the last time on this visit?

Q6. In TOTAL, during this visit, how much time will you have spent in the undeveloped areas of this National Forest? 


\section{Section 2: National Forest Visit Questions}

Q7. Did you spend last night in the (say forest name) National Forest?

Q8. When did you first arrive at this National Forest on this recreation visit?

Q9. When do you plan to finish your visit to this National Forest?

Q10. On this visit to this National Forest, did you go or do you plan to go to any places for recreation other than this one?

Q10a. Did you enter or do you plan to enter a designated Wilderness at any time during this National Forest visit?

Q10b. Did you enter any undeveloped areas such as trails, forest roads, lakes/streams, or other natural areas during this National Forest visit?

Q10c. How many different lodging facilities, such as campgrounds, cabins, hotels or lodges, have you used or do you plan to use during this National Forest visit?

Q10d. How many different day use sites such as picnic areas, visitor centers, interpretive sites, swimming areas, or ski areas have you used or plan to use during this National Forest visit?

Q11. In which of the following activities have you participated or will you participate during this National Forest visit?

Q12. Which ONE of those is your primary activity for this recreation visit on this NF?

Q13. Including this visit, about how many times have you come to this National Forest for recreation in the past 12 months?

Q14. How many of those visits were to participate in the main activity you identified a moment ago?

Q15. About how many hours did you spend doing your main activity during this visit?

Q16. Overall, how satisfied or dissatisfied are you with your recreation experience on this National Forest during this visit, using a scale of 1 to 5 , where 1 means very dissatisfied and 5 means very satisfied? 


\section{Section 3: This Trip Away From Home}

Q17. About how far from your home did you travel to get here?

Q18. Which of the following choices best describe the purpose of your trip?

Q19. Are you staying overnight away from home on this trip?

Q20. How many total nights will you be away from home?

Q21. Of these, how many are within 50 miles of here?

Q22. What types of lodging are you using within 50 miles of here? 


\section{Section 4: Demographics}

Q23. How many people (including you) traveled here in the same vehicle as you?

Q24. How many of those people are less than 16 years old?

Q25. Now I would like to collect age and gender information on everyone in your group.

Q26. Are you?

- Hispanic or Latino

- Not Hispanic or Latino

- Refused

Q27. With which racial group(s) do you most closely identify? Select all that apply.

- American Indian/Alaska Native

- Asian

- Black/African American

- Native Hawaiian or other Pacific Islander

- White

- Refused 


\section{Economics Questions}

Q28a. If for some reason you had been unable to go to this National Forest for this visit, would you have?

- Gone somewhere else for the same activity

- Gone somewhere else for a different activity

- Come back another time

- Stayed home

- Gone to work at their regular job

- None of these

Q28b. About how far away from home is the place you would have gone instead of here?

Q29. Trip Expenditure - Please estimate how much you (and other members of your party) will spend for your entire trip within 50 miles of here. Please round off to the nearest dollar.

Q30. In total how much did you and other people in your vehicle spend on this entire trip, from the time you left home until you return home?

Q31. What is your annual household income? 


\section{Satisfaction Questions}

Q28a. The Forest Service wants to make sure they provide recreation opportunities for everyone including those with disabilities. Does anyone in your group have a disability?

Q28b. Were the facilities or areas you visited accessible?

Q29. We are also interested in what you thought about the number of people who were using this area for recreation today. Please rate your perception on a scale of 1 to 10 , where 1 means there was hardly anyone else there, and 10 means that you thought the area was very over crowded.

Q30. I would like you to rate your satisfaction with each item on this list, with one meaning very dissatisfied and five meaning very satisfied. And then rate how important that item is on this visit, with 1 as very unimportant and 5 as very important.

Q30a. Adequacy of signage on this forest as a whole

Q30b. Signage Importance

Q31a. Condition of roads on this forest as a whole

Q31b. Road condition importance

Q32a. Scenery at this site/area

Q32b. Importance of Scenery

Q33a. Condition of the natural environment

Q33b. Importance of the natural environment condition

Q34a. Available Parking

Q34b. Importance of available parking

Q35a. Parking lot condition

Q35b. Importance of the parking lot condition

Q36a. Cleanliness of restrooms

Q36b. Importance of restroom cleanliness 
Q37a. Condition of developed recreation facilities

Q37b. Importance of the condition of developed recreation facilities

Q38a. Condition of forest roads

Q38b. Importance of forest road condition

Q39a. Condition of forest trails

Q39b. Importance of forest trail conditions

Q40a. Feeling of safety

Q40b. Importance of feeling safe

Q41a. Helpfulness of employees (not interviewer)

Q41b. Importance of employee helpfulness

Q42a. Availability of interpretive/educational displays, signs and exhibits

Q42b. Importance of interpretive/educational displays, signs and exhibits

Q43a. Value for fee paid (for fee sites only, this question only populates for certain proxy sites)

Q43b. Importance of fee paid value (for fee sites only)

Q44b. Importance of site information availability

Q45a. Adequacy of signage to this site

Q45b. Importance of signage adequacy 